Review

\title{
Long Non-Coding RNAs in Haematological Malignancies
}

\author{
Andoni Garitano-Trojaola ${ }^{1}$, Xabier Agirre ${ }^{1}$, Felipe Prósper ${ }^{1,2}$ and Puri Fortes ${ }^{3, *}$ \\ 1 Laboratory of Myeloproliferative Syndromes, Oncology Area, \\ Foundation for Applied Medical Research, University of Navarra, Pamplona 31008, Spain; \\ E-Mails: agaritano@alumni.unav.es (A.G.-T.); xaguirre@unav.es (X.A.); fprosper@unav.es (F.P.) \\ 2 Hematology Service and Area of Cell Therapy, University of Navarra Clinic, \\ University of Navarra, Pamplona 31008, Spain \\ 3 Department of Hepatology and Gene Therapy, Foundation for Applied Medical Research, \\ University of Navarra, Pamplona 31008, Spain \\ * Author to whom correspondence should be addressed; E-Mail: pfortes@unav.es; \\ Tel.: +34-948-194-700; Fax: +34-948-194-718.
}

Received: 31 May 2013; in revised form: 28 June 2013 / Accepted: 9 July 2013 /

Published: 24 July 2013

\begin{abstract}
Long non-coding RNAs (lncRNAs) are functional RNAs longer than 200 nucleotides in length. LncRNAs are as diverse as mRNAs and they normally share the same biosynthetic machinery based on RNA polymerase II, splicing and polyadenylation. However, lncRNAs have low coding potential. Compared to mRNAs, IncRNAs are preferentially nuclear, more tissue specific and expressed at lower levels. Most of the lncRNAs described to date modulate the expression of specific genes by guiding chromatin remodelling factors; inducing chromosomal loopings; affecting transcription, splicing, translation or mRNA stability; or serving as scaffolds for the organization of cellular structures. They can function in cis, cotranscriptionally, or in trans, acting as decoys, scaffolds or guides. These functions seem essential to allow cell differentiation and growth. In fact, many lncRNAs have been shown to exert oncogenic or tumor suppressor properties in several cancers including haematological malignancies. In this review, we summarize what is known about lncRNAs, the mechanisms for their regulation in cancer and their role in leukemogenesis, lymphomagenesis and hematopoiesis. Furthermore, we discuss the potential of lncRNAs in diagnosis, prognosis and therapy in cancer, with special attention to haematological malignancies.
\end{abstract}


Keywords: lncRNAs; leukemia; hematologic malignancies

\section{Introduction}

Transcriptome analysis by tiling arrays and RNA sequencing has led to the amazing conclusion that while $70 \%-90 \%$ of the genome is transcribed, only $2 \%$ is dedicated to the transcription of protein coding sequences [1]. This result has caused a great impression in a scientific community that is deeply proteocentric, i.e., is dedicated to the study of proteins and generally does not pay much attention to other molecules such as lipids or RNAs.

Most cellular RNA is composed of highly expressed non-coding RNAs whose relevance in cell functionality has been well-known for years. However, their transcription requires a relatively small proportion of the genome. These housekeeping non-coding RNAs include transfer RNAs (tRNAs) and ribosomal RNAs (rRNAs), required for mRNA translation; small nuclear RNAs (snRNAs), essential for splicing; and small nucleolar RNAs (snoRNAs), involved in RNA modification. More recently, several small RNAs have been described as playing essential roles in gene expression and transposon silencing. These include microRNAs (miRNAs), small interfering RNAs (siRNAs) and piwi interacting RNAs (piRNAs). Less clear is the role and the molecular mechanisms involved in the function of other small RNAs derived from retrotransposons or 3' untranslated regions or associated with transcription start sites, promoters, termini or repeats. All these non-coding RNAs, with the exception of some of the housekeeping RNAs (some rRNAs and a few snRNAs and snoRNAs), share the common characteristic of being smaller than $200 \mathrm{nts}$. Therefore the remaining non-coding RNAs, longer than $200 \mathrm{nts}$, have been grouped under the name of long non-coding RNAs (lncRNAs).

LncRNAs have a terrible name. They are not really long, just longer than the limit of $200 \mathrm{nts}$ imposed by small RNAs. In fact, the average size of coding mRNAs is near 2500 nts while the average length of all the lncRNAs recently described by the Encode project is less than $600 \mathrm{nts}$ [2]. Thus, most of the long non-coding RNAs are shorter than the coding mRNAs, even if some of the lncRNAs may be longer than $100 \mathrm{kbs}$. Apart from not being really long, it is difficult to determine whether lncRNAs are indeed non-coding. Traditionally, IncRNAs have been characterized by what they do not have: they lack open reading frames (ORFs) longer than 100 amino acids, conserved codons and homology to protein databases $[3,4]$. Therefore, they have poor coding potential, although they could still code for small open reading frames or non-conserved peptides. Some authors have also analyzed coding capacities of specific lncRNAs by matching their sequences with ribosome footprints or peptide fragments from mass spectrometry analysis. Hits would indicate translation [5-8]. In spite of these efforts, it should be borne in mind that what makes lncRNAs interesting for most scientists is not whether they can encode for proteins or not but the fact that they are functional as RNA molecules. The demonstration of function as an RNA should be required for annotation as an lncRNA, as a functional long RNA is the best definition for lncRNAs. To complicate things further, there are several cases of coding mRNAs that contain regulatory RNA elements and act as bifunctional RNAs; on one hand they code for a protein (p53, for instance) and on the other hand they have a function as 
RNAs [9-14]. Furthermore, several coding genes are transcribed to non-coding alternative splicing variants.

Functional or lncRNA genes are very similar to coding genes at the DNA and chromatin level as they share the same epigenetic marks. Similar to mRNAs, most lncRNAs are transcribed from RNA polymerase II, are capped at the $5^{\prime}$ end, contain introns and approximately $40 \%$ are polyadenylated at the 3 ' end [15]. The lncRNAs recently described by Encode show a bias for having just one intron and a trend for less-efficient cotranscriptional splicing $[8,16]$. It has been estimated that there could be as many lncRNA genes as coding genes, but the number of lncRNAs is still growing and some authors consider that it could increase from $\sim 20,000$ to $\sim 200,000$ [17,18]. Compared to mRNAs, most lncRNAs localize preferentially to the nucleus, are more cell type specific and are expressed at lower levels [19]. In fact, there is less than one copy per cell of many lncRNAs. The low expression levels and the fact that the sequence of lncRNAs is poorly conserved have convinced many scientists that they are not relevant for cell functionality. However, although lncRNAs are under lower selective pressure than protein-coding genes, sequence analysis shows that lncRNAs are under higher selective pressure than ancestral repeat sequences with neutral selection. Moreover, promoters of lncRNAs have similar selection levels than promoters of protein coding genes [8]. Even in the absence of strong sequence conservation, the genomic location and structure of many lncRNAs is conserved together with short stretches of sequences, suggesting that lncRNAs could be under selective pressure to maintain a functional RNA structure rather than a linear sequence [8].

Recent publications in the field have led to the hypothesis that many lncRNAs may be key regulators of development and may play relevant roles in cell homeostasis and proliferation. In fact, several lncRNAs have been described that function as oncogenes or tumor suppressors [20]. It is expected that for cell biology the role of lncRNAs could be as revolutionary as the role of small non-coding RNAs such as miRNAs. miRNA studies have highlighted the relevance of gene regulation in cell homeostasis, differentiation and proliferation and may impact the clinic with new therapies and new diagnostic and prognostic tools for many diseases. The relevance of miRNAs has been clearly established for haematological malignancies [21,22]. In this review we will summarize what is known about lncRNAs in normal haematopoiesis and in haematological tumors. Even though many more studies need to be done, the results obtained thus far suggest that several lncRNAs may be key molecules in haematopoiesis and in the pathogenesis of haematological malignancies.

\section{Classes of IncRNAs and IncRNA Functionality}

\subsection{Classification by Genomic Location}

Under the name of lncRNAs there are RNAs with many different characteristics, which complicates classification. Therefore a well accepted method is based on genomic location rather than on functionality, conservation or origin. From a genetic point of view lncRNAs can be classified into one or more of the following categories: (a) sense, when overlapping with one or more exons of another transcript in the same strand; (b) antisense, when overlapping with one or more exons of another transcript in the opposite strand; (c) intronic, when derived from an intron of another transcript; (d) divergent or bidirectional, when they share a promoter with another transcript in the opposite strand 
and therefore are coregulated; (e) intergenic, when they are independent, located in between two other genes. Long intergenic non coding RNAs (lincRNAs) are a special class of intergenic lncRNAs whose genes have histone mark signatures of active transcription (trimethylation in lysine 4 and lysine 36 of histone 3: H3K4m3, H3K36m3) [23].

In the case of antisense transcripts, classification based on genomic location helps to predict functionality. $50 \%-70 \%$ of sense transcripts have natural antisense partners (NATs) [24-26]. NATs are generally involved in the regulation in cis of the corresponding sense RNA by mechanisms that act at the transcriptional and posttranscriptional level. NATs can induce transcriptional interference or recruit chromatin modifiers and remodelers to establish a local transcriptionally active or inactive chromatin conformation [27]. Posttranscriptionally, examples of NATs exist that regulate imprinting, RNA editing, splicing, by blocking binding of the spliceosome to the 5' splice site of an intron leading to intron retention [28-32] or translation and stability by forming a duplex with the sense RNA that masks the binding site for miRNAs [33]. Thus, NATs can modify processing and induce or reduce the expression or the translation of their sense counterpart. Some intronic lncRNAs also regulate the expression of their genomic partners. Intronic lncRNAs may be generated by stabilization of the intron after splicing of the host gene but, more commonly, they are produced from independent transcription. Some intronic non-coding RNAs are associated with polycomb-related repressive histone marks along the promoter region and gene body of their host gene, which results in local transcriptional silencing [34].

\subsection{Classification by Specific Characteristics}

Most lncRNAs with special characteristics cannot be easily classified into a single group according to genomic location. These include enhancer RNAs (eRNAs), lncRNA-activating (lncRNA-a) genes, transcribed ultraconserved regions (T-UCRs), pseudogenes, telomere-associated ncRNAs (TERRAs), circular RNAs, etc.

eRNAs are transcribed by RNA polymerase II at active enhancer regions, characterized by H3 Lys4 monomethylation or Lys27 acetylation and binding of the regulatory protein p300 [35-39]. eRNAs are not polyadenylated. Many are bidirectional and poorly expressed [38,40], but expression of several eRNAs seems to be tightly regulated $[38,39]$. Although many eRNAs were thought to be by-products of the presence of RNA pol II in enhancers, recent evidence suggests that some may function to control the expression of neighbouring genes [41]. eRNAs are also important in the formation of the chromosomal loopings that bring enhancers closer to promoters [39], and in the induction of, for example, p53-dependent enhancer activity and transcription [42].

lncRNA-a genes generally transcribe intergenic RNAs which are involved in the expression of neighbouring genes [41]. Thus, downregulation of the lncRNA-a results in downregulation of the neighbour gene. This effect requires expression of the Mediator complex and it has been shown that interaction of the lncRNA-a with Mediator is required for the upregulation of nearby genes [43].

T-UCRs and pseudogenes are lncRNAs that share sequence similarity to other mammalian genomes or other regions of the same genome, respectively. There are 481 UCRs longer than $200 \mathrm{bp}$ that are absolutely conserved between human, rat, and mouse genomes [44]. Most are transcribed or T-UCRs in normal human tissues, both ubiquitously and tissue specifically. The high degree of conservation across species implies that T-UCRs may be essential, but deletion of some of these regions in knockout 
mice has not been associated with a detectable phenotype [45]. One possible function of some T-UCRs is miRNA control, as many T-UCRs have significant antisense complementarity with particular miRNAs and there is a negative correlation between expression of specific T-UCRs and predicted antisense miRNAs targets [46,47]. In fact, some T-URCs have been shown to be targeted by miRNAs.

Pseudogenes originated from duplication of ancestor or parental coding genes (duplicated pseudogenes) or through retrotransposition of processed RNAs transcribed from ancestor genes (processed pseudogenes). Subsequently, they have lost their coding capacity as a result of the accumulation of mutations. When pseudogenes are expressed, they may regulate the expression and function of their parental gene by several mechanisms [48,49]. For instance, pseudogenes may act as miRNA decoys that lead to increased stability and translation of their parental gene [50-53].

Circular RNAs, newcomers to the RNA list, can also function as RNA decoys [54-56]. It is generally accepted that circular RNAs originate from reverse splicing, where the acceptor splice site located downstream binds to an upstream donor splice site. This causes the circularization of the RNA and a tremendous increase in RNA stability, as circular RNAs lack 5' or 3' ends and therefore, are resistant to exonucleases. The increased stability of circular RNAs may lead to long-term functionality by miRNA sequestration [57].

\subsection{Classification as cis or trans-Acting Molecules}

LncRNAs can also be classified according to their functionality as cis and/or trans acting molecules (Figure 1). Trans-acting lncRNAs function away from the site of synthesis while cis-acting lncRNAs function at the site of transcription to affect the expression of neighbouring genes. Several cis-acting lncRNAs guide epigenetic regulators to their site of transcription while they are being transcribed. Thus, IncRNA transcription is critical and rapidly creates an anchor to recruit proteins involved in chromatin remodelling [58-61]. This molecular mechanism has tremendous advantages: (i) it responds very fast, as it only requires transcription of an RNA and a proper accumulation of nuclear chromatin remodelers; (ii) it is very specific, as the targeting does not involve RNA-DNA interactions other than those required for lncRNA transcription and (iii) it may function with just a single molecule of lncRNA per locus. This may explain the low abundance of cis-acting lncRNAs and the relatively high concentration of lncRNAs close to developmental genes whose expression is strictly controlled [62]. Thus, cis-acting lncRNAs control the epigenetic regulation of some imprinted genes. Imprinting depends on the parental origin of the imprinted genes, which play critical roles in mammalian development and therefore, their expression must be tightly regulated [63]. Many imprinted gene loci express lncRNAs that appear to regulate the expression of neighbouring imprinted protein-coding genes in cis, allele specifically [64]. The lncRNA $A I R$, for example, silences the neighbouring imprinted genes $S L C 22 A 3, S L C 22 A 2$ and IGF2R [65].

The clear division between cis and trans acting lncRNAs has been blurred by recent experiments, where exogenously expressed lncRNAs that normally work in cis, are able to find their target sites. Thus, even cis-acting lncRNAs may have the capacity to act in trans [65]. Furthermore, when considering cis-acting lncRNAs, the 3D organization of the genome should be taken into consideration. A cis-acting lncRNA may control the expression of neighbour genes brought into proximity by chromosome looping. 
Figure 1. Schematic representation of cis and trans-acting lncRNAs. cis-acting lncRNAs function at the site of transcription and affect the expression of neighbouring genes. Trans-acting lncRNAs function away from the site of synthesis.

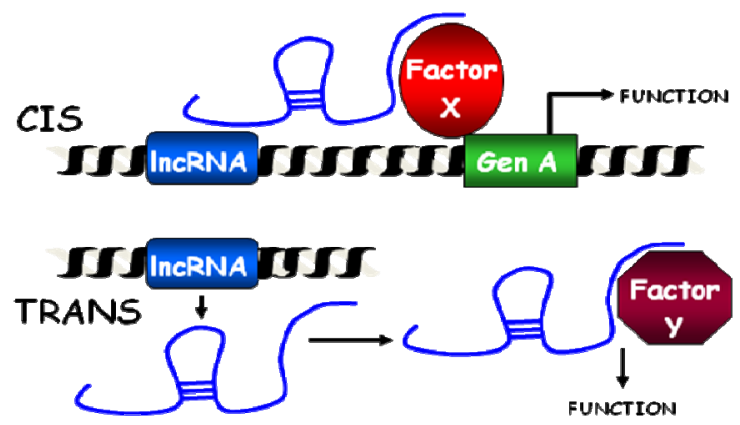

Trans-acting lncRNAs regulate gene expression on a genome-wide scale. A good example is HOTAIR, which binds the chromatin-modifying complexes PRC2, LSD1 and CoREST/REST [66-69]. Guiding chromatin remodelers to specific sites is easier to conceive for cis-acting lncRNAs. Targeting mediated by trans-acting lncRNAs would probably require RNA:DNA:DNA triplex formation via Hoogsteen base-pairing, as has been shown in vitro for a promoter-associated lncRNA [70]. However, such interactions may expose the genome to deamination and damage [71,72]. Furthermore, lncRNAs could form secondary and tertiary structures that behave similary to DNA-binding domains from proteins or that bind proteins that mediate DNA binding. This is what has been described for the XIST lncRNA, which binds YY1 transcription factor to reach specific sites in the X chromosome [73]. Theoretically, lncRNAs could also form an RNA:DNA hybrid that displaces a single strand of DNA (the so-called R-loop) or an RNA:RNA hybrid of lncRNA with a nascent transcript [74-76].

\subsection{IncRNA Functionality}

Guiding chromatin remodelling factors seems to be the predominant function exerted by lncRNAs. In fact, it has been estimated that $20 \%$ of all lncRNAs may bind PRC2 [66]. Several lncRNAs have also been shown to bind to PRC1, the CoREST/REST repressor complex [66], the histone methyltransferase associated with the activating trithorax complex, MLL1 [77,78], and H3-K9 methyltransferase, G9a [65,79]. However, lncRNAs have also been shown to exert several other functions in the cell nucleus and cytoplasm, including regulation of DNA bending and insulation, RNA transcription, splicing, translation and stability, organization of subnuclear structures and protein localization, among others.

DNA looping. CTCF can induce chromosomal bending and protect specific genes from the effects of distal enhancers and regulatory elements. The lncRNA SRA can interact with and enhance the function of CTCF [80]. Also, endogenous but not exogenous nascent HOTTIP lncRNA, binds target genes via chromosomal looping [81].

Transcription. LncRNAs may activate or inhibit transcription of specific targets. Some lncRNAs act as coactivators that bind transcription factors and enhance their transcriptional activity [82-84]. This is the function of $S R A \operatorname{lncRNA}$ in the progestin steroid hormone receptor [85,86]. However, some lncRNAs act as decoys of transcription factors [87] and may move them to the cytoplasm to keep them away from their nuclear targets [88]. Thus, p53-induced lncRNA PANDA binds transcription factor 
NF-YA and prevents NF-YA activation of cell death genes [89]. DHFR lncRNA forms a triplex structure which sequesters the general transcription factor IIB and prevents transcription of the DHFR coding gene [90]. Finally, the act of lncRNA transcription may interfere with transcription initiation, elongation or termination of another sense or antisense gene [91]. Transcriptional interference can also lead to activation of gene expression by inhibiting the action of repressor elements.

Organization of subnuclear structures. LncRNAs can recruit protein factors to nuclear structures. This is the case of lncRNA MALAT1 and NEAT-1. MALAT1 recruits serine/arginine-rich splicing factors to nuclear speckles [92]. More importantly, NEAT-1 is an essential structural component of paraspeckles, subnuclear structure implicated in RNA splicing and editing [93,94]. Depletion of NEAT-1 leads to loss of paraspeckles while overexpression of NEAT-1 causes an increase in the number of paraspeckles [95-97]. MALAT1 and NEAT-1 are genomic neighbours overexpressed in several tumors compared to healthy tissues. Surprisingly the mouse knockouts of either NEAT-1 or MALAT1 had no detectable phenotype, suggesting that there could be redundant or compensatory molecules [98-101].

Splicing. Splicing can be inhibited by lncRNAs antisense to intron sequences that impede spliceosome binding causing intron retention [28-32]. Furthermore, alternative splicing can be altered by IncRNA-mediated sequestration or modification of splicing factors. Thus, MALAT1 binds splicing factors present in nuclear speckles and modulates the activity of SR proteins, involved in the selection of splice sites, and therefore regulates the splicing of many pre-mRNAs [92]. Some snoRNA-containing lncRNAs (sno-lncRNAs) are retained close to their sites of transcription where the splicing factor Fox 2 is enriched. Changes in the level of the sno-lncRNA lead to a nuclear redistribution of Fox 2 and to changes in alternative splicing. Thus, the sno-lncRNAs could function as a regulator of splicing in specific subnuclear domains [102].

Translation. LncRNAs have been described that increase or inhibit translation of specific targets $[103,104]$. Expression of antisense UCHL1 lncRNA leads to an increase in Uchl1 protein level without any change at the Uchl1 mRNA level. A repetitive SINEB2 sequence is required for this function. Under cap dependent translation inhibition due to stress, UCHL1 lncRNA moves from the nucleus to the cytoplasm, binds to Uchll mRNA and allows its cap-independent translation. Thus, UCHL1 lncRNA could behave as a mobile internal ribosomal entry sequence.

Stability. LncRNAs have been described that increase or decrease stability of specific targets [105,106]. Binding of lncRNAs containing ancestral Alu repeats to complementary Alu sequences in the 3'UTR of coding mRNAs forms a dsRNA recognized by the dsRNA binding protein Stau1, which induces Stau-mediated RNA decay [106]. Instead, lncRNA TINCR localizes to the cytoplasm, where it interacts with Staul and promotes the stability of mRNAs containing the TINCR box motif [105].

miRNA binding. LncRNAs can regulate mRNA stability and translation by binding to miRNAs and preventing their action. Besides the already described role of some pseudogenes and circular lncRNAs in miRNA sequestration, other lncRNAs such as linc-MD1, have been shown to serve as "sponge" for miRNAs. Linc-MD1 binds two miRNAs, which downregulate transcription factors involved in muscle differentiation and therefore muscle differentiation is induced upon Linc-MD1 expression [107].

LncRNAs have been implicated in many other different functions. LncRNA $N R O N$ is a repressor of NFAT by binding $\beta$-importins and regulating the nuclear trafficking of NFAT [88]. TERC is a 
well-known telomerase-associated lncRNA that serves as a template for the synthesis of chromosome ends. The dsRNA-protein kinase PKR may be activated by binding to a lncRNA [108]. It is expected that in the near future novel and unexpected mechanisms of lncRNA functionality will be discovered. For instance, to date few lncRNAs have been described to have catalytic properties.

The high number of lncRNAs and their heterogeneity helps them to exert such a myriad of functions. In fact, all lncRNA functions respond to just three different mechanisms: decoys, scaffolds and guides [109]. Decoy-acting lncRNAs impede the access of proteins such as transcription factors and RNAs such as miRNAs to their targets. LncRNAs $M D-1$ and PANDA act as decoys for miRNAs and transcription factors, respectively [89,107]. Scaffold-acting lncRNAs serve as adaptors to bring two or more factors into discrete ribonucleoproteins (RNPs) [110]. LncRNA TERC, HOTAIR or NEAT-1 act as scaffolds to form the telomerase complex [111], a silencing complex [69] or the paraspeckle, respectively [93,94]. Guide-acting lncRNAs are required to localize protein complexes at specific positions. XIST or AIR lncRNAs act as guides to target gene silencing activity in an allele-specific manner. Guide lncRNAs such as HOTAIR, can also behave as scaffolds.

It is conceivable that lncRNAs may function through linear or structured domains. Linear domains may bind proteins but also RNA or, possibly, DNA sequences by perfect (e.g., antisense lncRNAs with their sense counterpart) or imperfect complementarity. Novel linear domains able to bind and regulate mRNAs, miRNAs or other lncRNAs could be very easily created evolutionarily. In many cases though, the secondary and tertiary structure of lncRNAs dictates their function. Thus, lncRNAs generally have complex structures with higher folding energies than those observed in mRNAs [112]. Proteins are expected to be the major partners of lncRNAs to form functional RNP particles. RNA binding proteins represent more than $15 \%$ of the total amount of proteins [113]. In several cases studied to date, interaction between proteins and RNAs results in conformational changes to the protein, the RNA or both, which could endow the complex with a novel ability.

LncRNA function impacts cell behaviour. LncRNAs have specially emerged as regulators of development. Some transcription factors involved in pluripotency bind promoter regions of more than 100 mouse lncRNAs [15]. 26 lincRNAs have already been described as being required for the maintenance of pluripotency in mouse [114]. Two lncRNAs regulated by pluripotency transcription factors such as Oct4 and Nanog are essential for pluripotency maintenance, as they, in turn, control the expression of Oct4 and Nanog [115]. Therefore, these lncRNAs participate in positive regulatory loops. Similarly, several lncRNAs have been implicated in human disease, including several cancers [116]. Dysregulated lncRNAs have been described in heart disease, Alzheimer disease, psoriasis, spinocerebellar ataxia and fragile $X$ syndrome [33,117-121] and in several tumours including breast, brain, lung, colorectal, prostate and liver cancers, melanoma, leukaemia and others [46,68,116,122-128]. LncRNAs have been described that function as oncogenes [129], tumour suppressors [23,130] or drivers of metastatic transformation, such as HOTAIR in breast cancer [68]. In this review we will concentrate on those lncRNAs whose expression is altered in haematological malignancies.

\section{LncRNAs Deregulated in Haematological Malignancies}

The impact of non-coding RNAs on haematological malignancies has been well described for microRNAs [131,132]. The list of lncRNAs involved in the initiation and progression of blood tumors 
is still very short and expected to grow exponentially in the near future. Some of the lncRNAs that play a role in haematological malignancies (Table 1) are in fact host genes of miRNAs with oncogenic or tumour suppressor properties. Others endow oncogenic or tumour suppressor properties in the long non-coding RNA molecule. The mechanism of action of few of them has been studied in some detail.

\subsection{Host Genes of Small RNAs}

\subsubsection{BIC and C13ORF25}

Some lncRNAs were described to have oncogenic properties in blood cells before the discovery of miRNAs. This is the case of the B cell Integration cluster (BIC) or host gene mir-155 (MIR155HG) (Figure 2A). BIC and miR-155 expression is increased in Hodgkin lymphoma, Acute Myeloid Leukemia (AML) and Chronic Lymphocytic Leukemia (CLL) but it is not detected in healthy samples [133]. Increased expression of BIC and $m i R-155$ results from transcription activation by the MYB transcription factor [134] and leads to $m i R-155$-mediated downregulation of several tumor suppressor genes [135]. In this case, the lncRNA BIC plays an important role in the regulation of miR-155 which is directly involved in the lymphomagenesis or leukemogenesis. Similarly, C13ORF25 or host gene mir-17 (MIR17HG) encodes the miR-17-92 cluster and its expression is increased in B-cell lymphoma [136], Mantle Cell Lymphoma (MCL) [137] and other tumors [138,139].

\subsection{2. $\mathrm{nc} 886$ or $v t R N A 2-1$}

$v t R N A 2-1$, previously known as pre-miR-886, is a short ncRNA suppressed in a wide range of cancer cells that inhibits activation of protein kinase R (PKR) [140]. Even if nc886 is shorter than $200 \mathrm{nts}$ and therefore is not a lncRNA, its relevance in AML merits a short description. $v t R N A 2-1$ is transcribed from the long arm of chromosome 5 region whose deletion is associated with poor outcome in AML. Furthermore, decreased expression by monoallelic or biallelic DNA methylation correlates with a worse outcome in AML patients [141]. Thus, vtRNA2-1 could be a tumour suppressor for AML and its role could be mediated by PKR. 
Table 1. IncRNAs in hematopoiesis and hematological malignancies.

\begin{tabular}{|c|c|c|c|c|c|c|}
\hline LncRNAs & LOCATION & $\begin{array}{c}\text { HEMATOLOGIC } \\
\text { DISEASE/SYSTEM } \\
\end{array}$ & FUNCTION & MOLECULAR MECHANISM & $\begin{array}{l}\text { MECHANISMS INVOLVED IN } \\
\text { DYSREGULATION }\end{array}$ & CITATIONS \\
\hline MIR155HG BIC & $21 \mathrm{q} 21.3$ & $\begin{array}{l}\text { Burkitt, Hodgkin lymphoma, } \\
\text { AML, CLL }\end{array}$ & Host of miRNAs & miR-155 & Target MYB and NFKB & {$[134]$} \\
\hline MIR17HG & $13 \mathrm{q} 31.3$ & B-cell lymphoma, MCL & Host of miRNAs & miR-17-92 & Target MYC & {$[136,137,142]$} \\
\hline$v t R N A 2-1$ & $5 \mathrm{q} 31.1$ & AML (poor prognosis) & & PKR inhibition & DNA methylation Deletion $5 q$ & {$[140,141]$} \\
\hline$P V T 1$ & $8 \mathrm{q} 24.21$ & $\begin{array}{l}\text { MM, Burkitt Lymphoma, } \\
\text { T-cell Leukemia, CLL }\end{array}$ & Oncogene and host of miRNAs & miR-1204 MYC activation & $\begin{array}{l}\text { Translocation } \mathrm{t}(8 ; 14)(\mathrm{q} 24 ; \mathrm{q} 11) \\
\mathrm{t}(2 ; 8)(\mathrm{p} 11 ; \mathrm{q} 24) \mathrm{t}(8 ; 22)(\mathrm{q} 24 ; \mathrm{q} 11)\end{array}$ & {$[143-148]$} \\
\hline $\begin{array}{c}\text { CDKN2B- } \\
\text { AS1/ANRIL }\end{array}$ & $9 \mathrm{p} 21.3$ & AML, ALL & Oncogene & PRC1 and PRC2 targeting & $\begin{array}{l}\text { rs3731217-G SNP Deletion, } \\
\text { hypermethylation }\end{array}$ & {$[26,128,149-151]$} \\
\hline MEG3 & $14 \mathrm{q} 32.2$ & AML,MM & Tumor suppressor & $\begin{array}{l}\text { PRC2 binding to control DLK1 } \\
\text { imprinting. } \\
\text { p53 activation. }\end{array}$ & DNA methylation & {$[149,150,152-155]$} \\
\hline DLEU1/DLEU2 & $13 \mathrm{q} 14.2$ & CLL, MM, Lymphoma & Tumor suppressor & $\begin{array}{l}\text { hsa-miR-16-1 and } 15 a \text { BCL2 } \\
\text { targeting. NFKB activation }\end{array}$ & $\begin{array}{l}\text { Histone modification, DNA } \\
\text { methylation, deletion }\end{array}$ & {$[156]$} \\
\hline GAS5 & $1 \mathrm{q} 25.1$ & B-cell Lymphoma, Leukemia & Tumor suppressor & $\begin{array}{l}\text { Glucorticoid receptor repression. } \\
\text { Regulated by mTOR pathway. }\end{array}$ & Translocation $(1 ; 3)(\mathrm{q} 25 ; \mathrm{q} 27)$ & [87] \\
\hline$H 19$ & $11 \mathrm{p} 15.5$ & $\begin{array}{l}\text { AML, CML, MPN, T-cell } \\
\text { Leukemia, Lymphoma }\end{array}$ & Oncogene/tumor suppressor & $\begin{array}{l}\text { Activated by Myc and down-regulated } \\
\text { by } 553 \text {. miR- } 675 \text { targeting } R b\end{array}$ & Loss of imprinting & [157] \\
\hline$T-U C R s$ & & CLL (prognosis marker) & Oncogene/tumor suppressor & miR control & & [46] \\
\hline $\operatorname{lincRNA-p21}$ & $\begin{array}{l}\text { Not annotated in } \\
\text { human }\end{array}$ & ALL, CML & Tumor suppressor & $\begin{array}{l}\text { Activated by } \mathrm{p} 53 \text { binds hnRNP K to } \\
\text { induce apoptosis }\end{array}$ & Not known & {$[158]$} \\
\hline$T C L-6$ & $14 \mathrm{q} 32.13$ & $\mathrm{~T}$ cell leukemia & Poorly characterized & Not described & $\begin{array}{c}\text { Translocation and inversions with } \\
\text { TCR }\end{array}$ & {$[151]$} \\
\hline$W T 1-A S$ & $11 \mathrm{p} 13$ & AML, ALL & Poorly characterized & WT-1 control & Not known & [159] \\
\hline CRNDE & $16 \mathrm{q} 12.2$ & AML, MM, T-cell leukemia & Oncogene & PRC2 and COREST binding & Not known & [160] \\
\hline$R M R P$ & $9 \mathrm{p} 13.3$ & Non-Hodgkin lymphoma & Poorly characterized & Not described & Mutation & [161] \\
\hline SNHG5 & $6 \mathrm{q} 14.3$ & B-cell Lymphoma & Poorly characterized & snoRNA host & Translocation $(1 ; 3)(\mathrm{q} 25 ; \mathrm{q} 27)$ & {$[162]$} \\
\hline HOXA-AS2 & $7 \mathrm{p} 15.2$ & APL & Poorly characterized & & Not known & [163] \\
\hline HOTAIRMI & $7 \mathrm{p} 15.2$ & Hematopoietic regulator & Regulator of myelopoiesis & HOX A genes. & & [164] \\
\hline EGOT & $3 \mathrm{p} 26.1$ & Hematopoietic regulator & $\begin{array}{c}\text { Regulator of } \\
\text { eosinophil development }\end{array}$ & & & [165] \\
\hline PU.1-AS & $\begin{array}{c}11 \mathrm{p} 11.2 \\
\text { Non annotated }\end{array}$ & Hematopoietic regulator & $\begin{array}{l}\text { PU.1-AS regulate the } \\
\text { hematopoiesis regulator PU.1 }\end{array}$ & PU.1 control & & {$[166]$} \\
\hline EPS & Mouse $4 \mathrm{qC} 7$ & Hematopoietic regulator & Regulator of erytropoyesis & Pycard repression & & [167] \\
\hline ThyncR1 & $1 \mathrm{q} 23.1$ & Hematopoietic regulator & $\begin{array}{c}\text { Regulator of } \mathrm{T} \text { cell } \\
\text { selection and maduration. }\end{array}$ & Riboregulator & & {$[168]$} \\
\hline
\end{tabular}


Figure 2. Schematic representation of the function of lncRNAs deregulated in haematological malignancies. (A) BIC. Myb transcription factor increases the expression of BIC in several leukemias and lymphomas. This results in increased levels of $m i R-155$ and $m i R$-155-mediated downregulation of several tumor suppressor genes; (B) ANRIL. The INK4 p15INK4b-p14ARF-p16INK4a cluster transcribes for an antisense transcript named ANRIL; PcG complex (PRC2) is targeted to the INK4 locus by ANRIL, and locus expression is inhibited; (C) MEG3. MEG3, among other functions, stimulates p53-dependent tumor suppressor pathways by several mechanisms. MEG3 down-regulates MDM2 expression, therefore decreasing p53 MDM2-mediated degradation. MEG3 increases p53 protein levels and stimulates p53-dependent transcription. $M E G 3$ enhances p53 binding to some target promoters such as GDF15; (D) GAS5. GAS5 binds the DNA binding domain of glucocorticoid receptors (GR) and impedes GR binding to DNA and induction of GR-dependent genes such as $c I A P 2$.

A
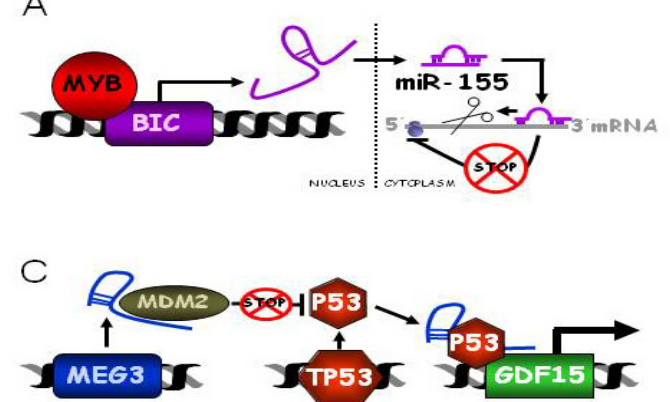

B

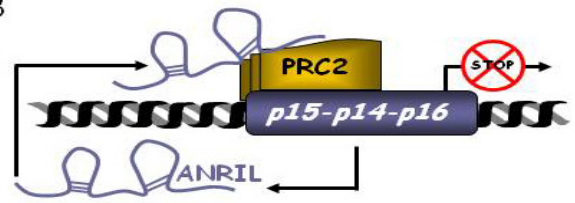

D

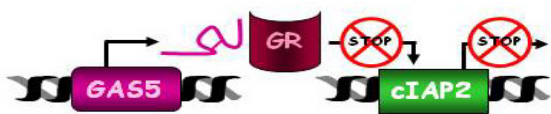

\subsubsection{PVT1}

It is not clear whether the role of Plasmacytoma variant translocation 1 (PVT1) lncRNA in haematological malignancies depends exclusively on being a miRNA host gene. The PVT1 gene is transcribed to several mature RNAs by alternative splicing, including a cluster of seven miRNAs, six of them annotated in the miRBase as miR-1204, miR-1205, miR-1206, miR-1207-5p, miR-1207-3p, and $m i R-1208$. The function of these miRNAs is unknown with the exception of miR-1204. miR-1204 has been involved in different roles related to development, differentiation and senescence [146,169]. On one hand miR-1204 has been described as increasing p53 levels and causing cell death [148]. In fact PVT1 expression is induced in response to p53 [148]. On the other hand, $m i R-1204$ has been shown to activate Myc and cell proliferation in mouse pre- B cell lines [146,147].

PVT1 is located in chromosome region 8q24.21, relatively close to the transcription factor c-Myc. Translocations within c-Myc or PVT1, which cause the overexpression of these two oncogenes compared to healthy cells, are characteristics associated with B cell malignancies including Burkitt Lymphoma (BL), AIDs, Non-Hodgkin lymphoma, mouse plasmacytoma (Pct) and multiple myeloma (MM) [147]. Furthermore, PVT1 is in a susceptibility locus for classical Hodgkin's lymphoma [145] and a SNP that causes increased PVT1 expression is associated with prostate cancer risk [170]. PVT1 is overexpressed, compared to healthy tissues, in breast and ovarian cancer, pediatric malignant astrocytomas, AML and Hodgkin lymphoma [171], suggesting that PVT1 could be an oncogene. In fact, upregulation of PVT1 contributes to tumor survival and chemoresistance [171-174] while its 
downregulation inhibits cell proliferation and induces a strong apoptotic response [171]. It has been proposed that PVT1 regulates c-Myc expression but also that PVT1 is regulated by c-Myc [175]. However, some authors suggest that Myc and PVT1 contribute to cancer by different mechanisms [147,171]. Further studies are required to understand the role of PVT1 in tumorigenesis and to determine whether the miRNAs encoded by $P V T 1$ mediate its functionality.

\subsection{LncRNAs with Oncogenic Properties}

ANRIL or CDKN2B-ASI

Antisense Non-coding RNA in the INK4 Locus (ANRIL) or CDKN2B-AS1 is transcribed antisense to the $p 15 I N K 4 b-p 14 A R F-p 16 I N K 4 a$ cluster, whose members are key effectors of oncogene-induced senescence (Figure 2B). The INK4 proteins are induced during aging and in premalignant lesions, limiting tumor progression. Therefore, expression of the INK4b-ARF-INK4a locus is tightly controlled and the Polycomb group (PcG) complexes are required to initiate and maintain silencing of this locus [176,177]. PcG complexes are targeted to the locus by ANRIL [178]. Depletion of ANRIL disrupts binding of the PRC2 component SUZ12 to the locus, increases the expression of p15INK4b and inhibits cellular proliferation. ANRIL, as a pol II nascent transcript, also controls cellular lifespan by targeting the PRC1 component CBX7 to the INK4 locus [27].

Genome-wide association studies revealed that $A N R I L$ is located in a genetic susceptibility locus (9p21) associated with several diseases, including coronary artery disease (CAD), atherosclerosis, intracranial aneurysm, type 2 diabetes, and several cancers, such as glioma, basal cell carcinoma, nasopharyngeal carcinoma, and breast cancer [179]. Several single nucleotide polymorphisms (SNP) in this locus alter ANRIL structure [180] and ANRIL gene expression [181,182], mediating susceptibility to disease. There is a statistically significant association between an ANRIL polymorphism and Philadelphia positive Acute Lymphoblastic Leukemia (Ph+ ALL) [183]. Furthermore, 69\% of samples $(n=16)$ from patients with ALL and AML showed relatively increased expression of $A N R I L$ and downregulated p15 compared to controls [130]. The expression of $A N R I L, \mathrm{CBX} 7$, and EZH2 is coordinated and elevated in preneoplastic and neoplastic tissues, leading to decreased p16INK4a expression and decreased senescence [27]. In fact, the INK4b-ARF-INK4a locus is subject to frequent deletion or hypermethylation in cancers, including leukemia, melanoma, lung and bladder cancers [177].

\subsection{LncRNAs with Tumor Suppressor Properties}

\subsection{1. $M E G 3$}

The maternally expressed gene 3 (MEG3) was the first lncRNA proposed to function as a tumor suppressor (Figure 2C). MEG3 is a paternally imprinted polyadenylated RNA, expressed in many normal human tissues as several alternative splicing variants [184,185]. MEG3 expression was decreased compared to healthy tissues in various brain cancers (pituitary adenomas, glioma and the majority of meningiomas and meningioma cell lines) [149,154], bladder, lung, renal, breast, cervix, colon and prostate cancers and haematological malignancies such as MM, AML or myelodysplastic 
syndromes. Surprisingly MEG3 is overexpressed in Wilms tumor and may be increased or decreased in different hepatocellular carcinomas versus healthy livers [186].

The last intron of MEG3 lncRNA encodes the evolutionarily conserved miR-770 [187] and MEG3 isoforms can contain several small open reading frames that are not required for MEG3 function $[152,153]$. Instead, the $M E G 3$ secondary structure, rather than primary sequence, is critical to maintaining function [152]. MEG3 lncRNA localizes to the nucleus, although some cytoplasmic $M E G 3$ transcripts have been detected $[184,188,189]$. In the nucleus, $M E G 3$ binds to PRC2 to control the imprinting of the DLK1 locus, where MEG3 belongs. Furthermore, MEG3 stimulates both p53-dependent and p53-independent tumor suppressor pathways [149,150,152-155]. MEG3 activates the tumor suppressor protein p53 at different levels. On one hand MEG3 down-regulates MDM2 expression, therefore decreasing p53 MDM2-mediated degradation [150]. On the other hand, MEG3 significantly increases p53 protein levels and stimulates p53-dependent transcription [155]. Finally, MEG3 enhances p53 binding to some target promoters such as GDF15 [152,153]. Ectopic expression of $M E G 3$ RNA leads to p53 accumulation and inhibition of cellular proliferation [153,185]. Inactivation of $M E G 3$ in the brain increases the expression of genes involved in angiogenesis, suggesting that the tumour suppressor function of $M E G 3$ works, in part, by inhibiting angiogenesis [190]. In bladder cancer a negative correlation has been shown between MEG3 expression and autophagy [191].

\subsubsection{DLEU1 and DLEU2}

Deleted in leukemia 1 (DLEU1) and 2 (DLEU2) are two genes transcribed head to head in a 30-kb region located in the long arm of chrormosome 13 (13q14), which is lost in more than $50 \%$ of patients with CLL and that predicts a poor prognosis [192]. The homozygous loss of this region has great effects on the regulation and control of normal CD5+ B lymphocytes and their homeostasis. Recent studies show that DLEU1 and DLEU2 control transcription of their neighbouring candidate tumour suppressor genes, which may act as positive regulators of NF-kB activity [156]. As binding of DLEU1 and DLEU2 to chromatin has not been detected, it has been proposed that they regulate neighbouring gene expression by divergent transcription. In addition, the intron 4 of DLEU2 encodes the miRNAs $h s a-m i R-16-1$ and $h s a-m i R-15 a$. This miRNA cluster exerts a crucial role in the tumorigenesis of CLL, in part, regulating the oncogene BCL2 [193]. Knocking out hsa-miR-16-1 and hsa-miR-15a in mice leads to a lymphoproliferative disease [194]. However the knockout model of DLEU2, which includes deletion of $h s a-m i R-16-1$ and $h s a-m i R-15 a$ as well, shows a more aggressive phenotype than the hsa-miR-16-1/hsa-miR-15a 6 knockout model alone, suggesting that DLEU2 can participate in CLL development on its own. In fact, increased expression of DLEU2 leads to reduced proliferation and clonogenicity [195].

\subsubsection{GAS5}

Growth arrest specific 5 (GAS5) is induced under starvation conditions and is highly expressed in cells that have arrested growth [196,197]. GAS5 modulates cell survival and metabolism by antagonizing the glucocorticoid receptor (GR) [87] (Figure 2D). GAS5 binds the DNA binding domain of GRs directly, preventing GRs from binding to DNA, from functioning as transcription activators and from reducing cell metabolism [87]. GAS5 could regulate other receptors (androgen, mineralocorticoid 
and progesterone but not estrogen receptors) by the same means [87]. Expression of GAS5 is sufficient to repress GR-induced genes, such as the cellular inhibitor of apoptosis 2 (cIAP2) and sensitizes cells to apoptosis [87]. Thus, GAS5 behaves as a tumor suppressor. GAS5 expression is decreased in breast cancer and is almost undetectable in growing leukemia cells and increases after density-induced cell cycle arrest $[87,196,197]$. At the same time, GAS5 has been shown to be regulated by the mammalian target of rapamycin (mTOR) pathway and to mediate the effect of rapamycin on the cell cycle in $\mathrm{T}$ cells [198]. Downregulation of GAS5 by RNA interference protects leukemic and primary human $\mathrm{T}$ cells from the anti-proliferative effect of rapamycin [199].

\subsection{LncRNAs with Dual Functions}

\subsection{1. $H 19$}

$H 19$ is an imprinted lncRNA located close to the IGF2 gene. H19 is expressed form the maternal allele and $I G F 2$ from the paternal allele $[59,200]$. A key feature of cancer is the loss of this imprinting, which results in the well documented overexpression of $H 19$ in cancers of the colon, liver, breast and bladder and in hepatic metastases, compared to healthy tissues [200-204]. Loss of H19 imprinting has been described in adult T-cell leukaemia/lymphoma (ATL) [157] and decreased H19 expression was found in the bone marrow of patients with clinically untreated chronic myeloproliferative disorders, including chronic myeloid leukemia (CML), polycythemia vera (PV), essential thrombocythemia (ET), primary myelofibrosis (PMF) and chronic myelomonocytic leukaemia (CMML) [205,206] and AML [207].

H19 can behave as an oncogene or as a tumour suppressor [59]. H19 expression can be activated by the oncogene c-Myc [200] and downregulated by the tumour suppressor p53 [208,209]. Downregulation of $H 19$ by RNAi blocks cell growth and clonogenicity of lung cancer cell lines [200] and decreases xenograft tumour growth of a hepatocellular carcinoma cell line [203]. Furthermore, H19 is the precursor of miR-675, which downregulates the tumor suppressor retinoblastoma in human colorectal cancer [210]. All these results indicate that H19 is an oncogene [210]. However, depletion of $H 19$ caused increased polyp count in a mouse model for colorectal cancer [211], larger tumor growth in a mouse teratocarcinoma model and an earlier development of tumours in a mouse hepatocarcinoma model [212]. This dual role as oncogene or tumour suppressor may depend on the cellular environment of the tumour type.

\subsubsection{T-UCRs}

The expression of many T-UCRs has been described to be significantly altered in tumours such as CLL, colorectal and hepatocellular carcinomas and neuroblastomas [46,162,213,214]. Certain SNPs in T-UCR genes were associated with increased familial breast cancer risk [163]. Moreover, T-UCR transcription profiles can be used to differentiate types of human cancers and predict patient outcome [213]. Some T-UCRs seem tumour specific, such as UC.73A and UC.338, which are decreased in colon cancer [215]. In fact, some T-UCRs differentially expressed in a particular human cancer locate in fragile sites or cancer-associated genomic regions specifically associated with that type of cancer [216]. This is the case of UC.349A and UC.352, differentially expressed between 
normal and leukemic CD5-positive cells [46] and located within a chromosomal region linked to susceptibility to familial CLL [217]. Moreover, a profile of 19 T-UCRs (8 up- and 11 down-regulated) was able to differentiate between normal, CLL, colorectal, and hepatocarcinoma samples. Expression of five T-UCRs was able to divide a CLL cohort into two prognostic groups [46]. Expression of these diagnostic T-UCRs negatively correlated with a previously defined CLL miRNA signature, suggesting a mechanism for miRNA regulation of these T-UCRs [218].

\subsection{LncRNAs Poorly Characterized in Haematological Malignancies}

LincRNA-p21: is a p53 activated lncRNA identified in mouse that binds to and guides hnRNP K to target genes. LincRNA-p21 bound hnRNP $\mathrm{K}$ acts as a transcriptional repressor that leads to the induction of apoptosis [23]. As BCR-ABL1 stimulates hnRNP-K expression and stability and promotes tumor progression, it has been suggested that lincRNA-p21 could play a relevant role in acute or chronic leukemia [219,220]. Furthermore, lincRNA-p21 can inhibit the translation of target mRNAs [104]. In the absence of HuR, lincRNA-p21 is stable and interacts with the mRNAs CTNNB1, $J U N B$ and translational repressor Rck, repressing the translation of the targeted mRNAs [104].

TCL6: T cell Leukemia/Lymphoma 6 (TCLO) is transcribed from a locus involved in translocations and inversions with $\mathrm{T}$ cell receptor $(T C R)$ [221]. These rearrangements in TCR commonly lead to activation of TCL6 lncRNA and other oncogenes related to T cell leukemogenesis [151].

$\boldsymbol{W T 1 - A S}$ : is an antisense 1ncRNA to WT-1, a well-characterized developmental gene that is mutated in Wilms' tumor (WT) and AML. WT1-AS has been shown to regulate WT1 protein levels. $W T 1-A S$ binds the exon 1 of WT1 mRNA in the cytoplasm. It has been suggested that the abnormal splicing of WT1-AS in AML could play a role in the development of this malignancy [159].

CRNDE: is overexpressed, compared to healthy tissue, in more than $90 \%$ of colorectal adenomas tested, but also in hepatocellular, prostate, brain, kidney and pancreas carcinomas and different haematological neoplasia such as AML, MM and T cell leukemia [160]. CRNDE has been described as downregulated in ovarian cancer and tends to be overexpressed in non-differentiated tissues versus differentiated controls [160]. CRNDE binds PRC2 and the downregulation of $C R N D E$ causes upregulation of PRC2 regulated genes, decreases growth and increases apoptosis [66].

RMRP: Ribonuclease mitochondrial RNA processing (RMRP) is a lncRNA mutated in Cartilage-Hair Hypoplasia $(\mathrm{CHH})$, an autosomal recessive chondrodysplasia with short stature, which entails a high risk of developing Non-Hodgkin lymphoma disease [161,222].

SNHG5: is a precurssor of snoRNAs, similar to GAS5, located at the breakpoint of the chromosomal translocation $\mathrm{t}(3 ; 6)(\mathrm{q} 27 ; \mathrm{q} 15)$, involved in diffuse large B-cell lymphoma [223].

HOXA-AS2: HOXA Cluster Antisense RNA 2 (HOXA-AS2) lncRNA is antisense to HOX3 and HOX4 coding genes. In an acute promyelocytic leukemia (APL) cell line, HOXA-AS2 upregulation correlated with inhibition of apoptosis. Treatment with all-trans retinoic acid (ATRA) blocked the expression of HOXA-AS2 and increased apoptosis of the APL cell line [224].

\section{LncRNAs Involved in Hematopoiesis}

The best studied lncRNA in hematopoiesis is HOTAIRMI (HOX antisense intergenic RNA myeloid 1). HOTAIRMI is as an essential regulator of myeloid cell differentiation that locates at the $3^{\prime}$ 
end of the HOXA cluster and controls HOXA1 expression [164]. HOXA genes are important transcriptional regulators in normal and malignant hematopoiesis and are known to be important for many cancers including leukemias harbouring MLL rearrangements. HOTAIRM1 is expressed specifically in the myeloid lineage and is induced during the retinoic acid-driven granulocytic differentiation of the NB4 promyelocytic leukaemia cell line and normal human hematopoietic cells. Knockdown of HOTAIRMI affects retinoic acid-induced expression of HOXA1 and HOXA4 (but not distal $H O X A$ genes) and attenuates induction of myeloid differentiation genes [164].

Other IncRNAs involved in hematopoiesis have also been described. EGO (or EGOT in human) lncRNA was identified in mouse eosinophil differentiation of CD34+HSCs where it stimulated major basic protein and eosinophil-derived neurotoxin mRNA expression [165]. The lncRNA PU.1-AS is an antisense transcript of $P U .1$ that negatively regulates $P U .1$ mRNA translation by a mechanism similar to miRNAs [166]. PU.1 is a master hematopoietic transcriptional regulator essential for normal hematopoietic development and suppression of leukaemia development. LincRNA erythroid prosurvival (EPS) is one of the about 400 lncRNAs whose expression is modulated during red blood cell formation and is required for differentiation during hematopoiesis in mouse [164,165,167]. EPS is an erythroid-specific lncRNA that represses expression of PYCARD, a proapoptotic gene, and therefore inhibits apoptosis [167,225]. EPS is not well conserved among mammals. It is presently unclear whether a human version of EPS exists. Finally, THY-ncRl is a thymus-specific lncRNA expressed in cell lines derived from stage III immature T cells in which the neighbouring CDI gene cluster is also specifically activated [168].

\section{Regulation of the Expression of IncRNAs Involved in Haematological Malignancies}

Altered expression of lncRNAs, similar to that of coding genes, can be the result of genomic alterations, epigenetic regulation or a change in response to transcription factors or stability effectors such as miRNAs.

The presence of mutations in the lncRNA primary sequence correlates highly with human diseases. In fact, most mutations in the genome occur in noncoding regions [226]. Mutations can be large or small. Large-scale mutations are deletions and amplifications of hundreds of nucleotides and chromosomal translocations occurring at fragile sites. Genome-wide analyses looking for fragile sites in lncRNA genes have not yet been performed. However, it is expected that lncRNAs will have a clear association with common chromosomal aberrations similar to that found for miRNAs in human haematological malignancies and carcinomas [46]. In fact, several studies have described lncRNAs affected by large scale mutations. One of the best examples is $A N R I L$, affected by a large germline deletion that includes the complete INK4/ARF locus. This deletion is associated with hereditary cutaneous malignant melanoma and neural system tumors syndrome [179]. DLEU1 and DLEU2 lncRNAs also locate in a region commonly deleted in CLL (see above).

Small scale mutations are deletions or insertions of a few nucleotides. The relevance of small scale mutations for lncRNAs is obscured by the fact that little is known about the relevance of the primary sequence in lncRNA functionality and expression. It is expected that small mutations can lead to disease if they affect relevant linear sequences or they alter the structure of domains important in lncRNA functionality or accumulation. In fact, several disease-associated SNPs have been described as 
affecting the structure of the 5' and 3' non-translated regions of coding genes [226]. Furthermore, GWAS studies have shown that SNPs in noncoding regions are associated with higher susceptibility to diverse diseases. Germline and somatic mutations in lncRNA genes have been identified in haematological malignancies and colorectal cancers [227]. SNPs that may affect ANRIL have been associated with increased risk of type 2 diabetes and increased susceptibility to coronary artery disease and atherosclerosis [228,229]. Some of these mutations did not affect $A N R I L$ transcription or stability. Instead, they disrupt $A N R I L$ splicing, resulting in a circular transcript, affecting normal $A N R I L$ function and influencing INK4/ARF locus expression [180]. Moreover, genetic aberrations of the GAS5 locus have been found in melanoma, breast and prostate cancers [230-232].

Several lncRNAs are regulated at the transcriptional level. Thus, lncRNAs, such as lincRNA-P21, are activated in response to DNA damage by the direct binding of the tumour-suppressor protein p53 to the promoter [23]. Similarly, the expression of several lincRNAs responds to pluripotency factors or oncogenes.

Epigenetic modifications are key regulators of lncRNA expression. This has been well described for $M E G 3$ and DLEU1/DLEU2. Expression of the MEG3 locus is regulated by two regions, which are hypermethylated in several solid tumours leading to downregulation of $M E G 3$ expression [185,233,234]. AML patients with aberrant hypermethylation of the MEG3 promoter showed decreased overall survival [235,236]. Thus, MEG3 methylation status may serve as a useful biomarker in this leukemia. A similar MEG3 hypermethylation was observed in $35 \%$ of the patients with myelodysplastic syndrome, but in this case there was no statistically significant correlation between MEG3 hypermethylation and prognosis [235]. Similarly, conserved $\mathrm{CpG}$ islands at the transcriptional start sites of DLEU1 and DLEU2 were found to be significantly demethylated in a cohort of 143 patients with CLL [156]. Demethylation correlated with transcriptional deregulation of the neighbouring candidate tumour suppressor genes. T-UCRs expression has also been shown to be repressed by CpG island hypermethylation [47,213].

Finally, the expression of lncRNAs can be regulated by miRNAs. Several miRNAs have been described as regulating T-URC expression. This has been best described for miR-155, which is overexpressed in CLL compared to healthy cells. miR-155 targets T-UCRs both in vitro and in CLL patient samples [46]. Interestingly, $m i R-29 a$ has also been shown to regulate MEG3 expression in hepatocarcinoma cell lines [186].

\section{Concluding Remarks}

The identification of lncRNAs and the functional relevance of the lncRNAs studied so far has changed the view about genomes, transcriptomes and gene expression regulation. As the lncRNA field is in its infancy, surprising results are still expected, but a tremendous amount of work needs to be done. Firstly, a systematic identification and annotation of lncRNAs and their expression patterns should be performed and made publically available. As most lncRNAs are tissue specific, all tissues should be profiled. Also, as there is poor sequence conservation between lncRNAs of different species, efforts should be devoted to describing a collection of lncRNAs in different species, including human, mouse, rat, zebra fish, fly, Arabidopsis and yeast. As the regulation of expression of lncRNAs is tightly controlled, lncRNAs should also be described in cells responding to different stimuli and in 
diseased cells. These studies will be complicated further by the fact that lncRNA genes may be transcribed to different transcripts by alternative splicing, polyadenylation and the use of different promoters. It is also necessary to develop a new universal nomenclature that would facilitate routine work with these non coding RNA molecules.

Secondly, functional studies should be performed. Gain and loss of function studies could be carried out to analyze the impact of the lncRNA on the cell phenotype. Transcriptome analysis coupled with gain and loss of function studies could provide clues regarding the cellular pathways affected by the lncRNA, especially if the lncRNA of interest is a regulator of the expression of specific genes. Analysis of lncRNA subcellular localization can also give clues to lncRNA functionality. This can be done with Fish-like techniques that use several labelled oligos at a time. This is essential to detect the expression of lncRNAs, which are generally very structured and not very abundant. The functional domains of lncRNAs should be identified and it should be ruled out that lncRNAs function through the translation of short peptides. Furthermore, it would be desirable to determine the structure of key domains in lncRNAs similarly to what has been done with proteins. This is a major task as there are no reliable methods to determine the secondary structures of lncRNAs with bioinformatic tools. Chemical probing and point mutation studies have been used to determine the structure of many RNAs, but these techniques are very time consuming. Faster results could be obtained by parallel analysis of RNA structure (PARS-Seq) or Frag-Seq, which uses deep sequencing of RNA fragments obtained from RNAs treated with specific RNases that cleave RNA at highly selective structural positions [237]. Furthermore, it would be interesting to identify the factors that bind to relevant lncRNAs. Ideally, specific RNAs should be immunoprecipitated and subjected to mass spectrometry to identify RNA binding proteins. This is not easy, but has been done successfully with pools of cellular RNAs purified by binding to oligodT beads [238]. Theoretically, a lncRNA of interest could be labelled with a domain targeted by a specific protein and the complex could be purified with antibodies specific to the protein. Alternatively, the lncRNA could be immunoprecipitated from cell extracts using biotinylated tiling oligos and streptavidin. Then, IncRNA bound DNA or RNA can be sequenced from the immunoprecipitates. When looking for DNA interactors, this technique has been named Chromatin Isolation by RNA Purification (ChIRP) and has allowed the identification of the natural regions of chromatin that interact with a given lncRNA [58]. Finally, the lncRNA can be transcribed and labelled in vitro, incubated with cell extracts and immunoprecipitated with label binding factors.

Finally, detailed analysis of functional lncRNAs will most probably reveal interesting cellular pathways and help to design the architecture of biological tools that may be of interest for biotechnological development. Domains of lncRNAs that function as decoys for miRNAs or transcription factors, mimicking GAS5 function [239], could be expressed to obtain therapeutic effects. Several lncRNA domains with a specific tertiary structure and a given function could probably be combined to generate lncRNAs with novel functions that could be of therapeutic interest. For instance, an RNA domain involved in the binding to a specific region of the chromatin could be fused to an RNA domain that interacts with factors that silence or activate gene expression or that induce chromosome bendings or genome reorganizations at the specific position. This could be used for silencing of oncogenes or reactivation of tumour suppressor genes. Thus, analysis of the function of lncRNAs is expected to have a tremendous impact on the management of human disease. 
Furthermore, strong associations between some lncRNAs and some human diseases have been described. The number of lncRNAs relevant to human diseases is expected to increase as a result of the systematic identification of lncRNAs whose expression is altered in healthy and diseased cells and by genome-wide association studies. In fact GWAS analysis has identified ANRIL as a lncRNA involved in atherosclerosis, coronary artery disease, and type 2 diabetes [179]. In the case of cancer and specifically of haematological malignancies, GWAS results at lncRNA loci may identify patient populations at risk of cancer, may classify patients into aggressive or mild cancer groups and may predict a patient's response to a given therapy [240,241]. Once lncRNAs related to a disease are described, the issue should be addressed whether they are useful signatures for early disease detection, for prognosis or can be used as candidate drug targets for disease intervention [242].

lncRNAs may have specific advantages when used as diagnostic biomarkers, as some show tissue-specific and cancer-specific expression patterns [243]. This is the case of $H U L C$, a liver-specific lncRNA highly expressed in primary liver tumours and hepatic metastases of colorectal carcinoma, but not found in primary colon cancers or in non-liver metastases [244,245]. Thus, the expression of HULC and other lncRNAs can be used to differentiate between subtypes of the same cancer or to identify unknown primary tumours. Similarly, PCGEM1, PCA3 or PRNCR1 are three lncRNAs exclusively associated with prostate cancer [123,246,247]. Also, as in the case with miRNAs, some lncRNAs can be detected in body fluids by quantitative reverse transcriptase polymerase chain reaction and therefore enable non-invasive diagnoses. In fact, $H U L C$ can be detected in the blood of hepatocellular carcinoma patients using qRT-PCR [245]. The ProgensaTM PCA3 urine test, a kit to detect $P C A 3$ in urine samples from patients with prostate cancer is already being clinically used [248,249]. This specific test can help patients who had a first negative prostate biopsy to avoid unnecessary repeated biopsies [250]. In spite of this fast clinical translation for $P C A 3$ analysis in prostate cancer, the biological function of $P C A 3$ is unknown.

LncRNAs can also be used as predictive markers, as lncRNA expression can correlate with patient outcome or response to chemotherapy. Thus, the expression of HOTAIR correlates with metastasis and poor outcome in primary breast tumors, gastrointestinal, hepatocellular and colorectal cancers and the expression of MALAT correlates with survival in early-stage lung adenocarcinoma [68,124,251-253]. Also, the expression of XIST correlates with disease-free survival of Taxol-treated cancer patients [254].

Finally, IncRNAs could be used therapeutically. In cancer, expression of tumour suppressor lncRNAs, such as GAS5 or MEG3, should decrease tumour growth. When the downregulation of tumour suppressor lncRNAs results from aberrant epigenetic mechanisms such as DNA hypermethylation or loss of histone acetylation, demethylating agents or histone deacetylase inhibitors could help to reestablish expression. Otherwise, expression of lncRNAs may require gene therapy delivery systems with viral vectors, which are not efficient in targeting all cells within a tumour. Furthermore, RNA interference can be used to decrease the expression of lncRNAs with oncogenic properties. While many lncRNAs have been silenced using siRNAs, it is generally believed that the secondary structure of lncRNAs hinders siRNA functionality. Instead, expression of lncRNAs with oncogenic or tumour suppressor molecules could be altered with small molecules that affect their promoters. Small molecules, aptamers or stable antisense oligonucleotides could also be identified that target essential structures for oncogenic lncRNA functionality. Thus, preventing the interactions of HOTAIR with PRC2, for example, may limit the metastatic potential of breast cancer cells [255]. Even if all these 
strategies are possible, much investment in this field will be required to transfer lncRNA research to clinical oncology.

\section{Acknowledgments}

Supported in part by grants from Ministerio de Ciencia e Innovacion and Instituto de Salud Carlos III (ISCIII) BIO2009/09295, SAF2012-40003, PI10/01691, PI10/02983, RD12/0036/0068, CP07/00215, FEDER funding, FP7 Marie Curie Program PIOF-GA-2012-330598 LincMHeM, funds from the "UTE project CIMA" and by the project RNAREG [CSD2009-00080], funded by the Ministry of Science and Innovation under the programme CONSOLIDER INGENIO 2010.

\section{Conflicts of Interest}

The author declares no conflict of interest.

\section{References}

1. Mattick, J.S. Non-coding RNAs: The architects of eukaryotic complexity. EMBO Rep. 2001, 2, 986-991.

2. Dunham, I.; Kundaje, A.; Aldred, S.F.; Collins, P.J.; Davis, C.A.; Doyle, F.; Epstein, C.B.; Frietze, S.; Harrow, J.; Kaul, R.; et al. An integrated encyclopedia of DNA elements in the human genome. Nature 2012, 489, 57-74.

3. Lin, M.F.; Carlson, J.W.; Crosby, M.A.; Matthews, B.B.; Yu, C.; Park, S.; Wan, K.H.; Schroeder, A.J.; Gramates, L.S.; St Pierre, S.E.; et al. Revisiting the protein-coding gene catalog of Drosophila melanogaster using 12 fly genomes. Genome Res. 2007, 17, 1823-1836.

4. Lin, M.F.; Deoras, A.N.; Rasmussen, M.D.; Kellis, M. Performance and scalability of discriminative metrics for comparative gene identification in 12 Drosophila genomes. PLoS Comput. Biol. 2008, 4, e1000067.

5. Pueyo, J.I.; Couso, J.P. Tarsal-less peptides control Notch signalling through the Shavenbaby transcription factor. Dev. Biol. 2011, 355, 183-193.

6. Ingolia, N.T.; Lareau, L.F.; Weissman, J.S. Ribosome profiling of mouse embryonic stem cells reveals the complexity and dynamics of mammalian proteomes. Cell 2011, 147, 789-802.

7. Banfai, B.; Jia, H.; Khatun, J.; Wood, E.; Risk, B.; Gundling, W.E., Jr.; Kundaje, A.; Gunawardena, H.P.; Yu, Y.; Xie, L.; et al. Long noncoding RNAs are rarely translated in two human cell lines. Genome Res. 2012, 22, 1646-1657.

8. Derrien, T.; Johnson, R.; Bussotti, G.; Tanzer, A.; Djebali, S.; Tilgner, H.; Guernec, G.; Martin, D.; Merkel, A.; Knowles, D.G.; et al. The GENCODE v7 catalog of human long noncoding RNAs: Analysis of their gene structure, evolution, and expression. Genome Res. 2012, 22, 1775-1789.

9. Kloc, M.; Wilk, K.; Vargas, D.; Shirato, Y.; Bilinski, S.; Etkin, L.D. Potential structural role of non-coding and coding RNAs in the organization of the cytoskeleton at the vegetal cortex of Xenopus oocytes. Development 2005, 132, 3445-3457. 
10. Wadler, C.S.; Vanderpool, C.K. A dual function for a bacterial small RNA: SgrS performs base pairing-dependent regulation and encodes a functional polypeptide. Proc. Natl. Acad. Sci. USA 2007, 104, 20454-20459.

11. Dinger, M.E.; Pang, K.C.; Mercer, T.R.; Mattick, J.S. Differentiating protein-coding and noncoding RNA: Challenges and ambiguities. PLoS Comput. Biol. 2008, 4, e1000176.

12. Leygue, E. Steroid receptor RNA activator (SRA1): Unusual bifaceted gene products with suspected relevance to breast cancer. Nucl. Recept. Signal. 2007, 5, e006.

13. Jenny, A.; Hachet, O.; Zavorszky, P.; Cyrklaff, A.; Weston, M.D.; Johnston, D.S.; Erdelyi, M.; Ephrussi, A. A translation-independent role of oskar RNA in early Drosophila oogenesis. Development 2006, 133, 2827-2833.

14. Candeias, M.M.; Malbert-Colas, L.; Powell, D.J.; Daskalogianni, C.; Maslon, M.M.; Naski, N.; Bourougaa, K.; Calvo, F.; Fahraeus, R. P53 mRNA controls p53 activity by managing Mdm2 functions. Nat. Cell Biol. 2008, 10, 1098-1105.

15. Guttman, M.; Amit, I.; Garber, M.; French, C.; Lin, M.F.; Feldser, D.; Huarte, M.; Zuk, O.; Carey, B.W.; Cassady, J.P.; et al. Chromatin signature reveals over a thousand highly conserved large non-coding RNAs in mammals. Nature 2009, 458, 223-227.

16. Tilgner, H.; Knowles, D.G.; Johnson, R.; Davis, C.A.; Chakrabortty, S.; Djebali, S.; Curado, J.; Snyder, M.; Gingeras, T.R.; Guigo, R. Deep sequencing of subcellular RNA fractions shows splicing to be predominantly co-transcriptional in the human genome but inefficient for lncRNAs. Genome Res. 2012, 22, 1616-1625.

17. Gibb, E.A.; Vucic, E.A.; Enfield, K.S.; Stewart, G.L.; Lonergan, K.M.; Kennett, J.Y.; Becker-Santos, D.D.; MacAulay, C.E.; Lam, S.; Brown, C.J.; et al. Human cancer long non-coding RNA transcriptomes. PLoS One 2011, 6, e25915.

18. Mercer, T.R.; Dinger, M.E.; Sunkin, S.M.; Mehler, M.F.; Mattick, J.S. Specific expression of long noncoding RNAs in the mouse brain. Proc. Natl. Acad. Sci. USA 2008, 105, 716-721.

19. Djebali, S.; Davis, C.A.; Merkel, A.; Dobin, A.; Lassmann, T.; Mortazavi, A.; Tanzer, A.; Lagarde, J.; Lin, W.; Schlesinger, F.; et al. Landscape of transcription in human cells. Nature 2012, 489, 101-108.

20. Hauptman, N.; Glavac, D. Long non-coding RNA in cancer. Int. J. Mol. Sci. 2013, 14, 4655-4669.

21. Agirre, X.; Jimenez-Velasco, A.; San Jose-Eneriz, E.; Garate, L.; Bandres, E.; Cordeu, L.; Aparicio, O.; Saez, B.; Navarro, G.; Vilas-Zornoza, A.; et al. Down-regulation of hsa-miR-10a in chronic myeloid leukemia CD34+ cells increases USF2-mediated cell growth. Mol. Cancer Res. 2008, 6, 1830-1840.

22. Agirre, X.; Vilas-Zornoza, A.; Jimenez-Velasco, A.; Martin-Subero, J.I.; Cordeu, L.; Garate, L.; San Jose-Eneriz, E.; Abizanda, G.; Rodriguez-Otero, P.; Fortes, P.; et al. Epigenetic silencing of the tumor suppressor microRNA Hsa-miR-124a regulates CDK6 expression and confers a poor prognosis in acute lymphoblastic leukemia. Cancer Res. 2009, 69, 4443-4453.

23. Huarte, M.; Guttman, M.; Feldser, D.; Garber, M.; Koziol, M.J.; Kenzelmann-Broz, D.; Khalil, A.M.; Zuk, O.; Amit, I.; Rabani, M.; et al. A large intergenic noncoding RNA induced by p53 mediates global gene repression in the p53 response. Cell 2010, 142, 409-419. 
24. Katayama, S.; Tomaru, Y.; Kasukawa, T.; Waki, K.; Nakanishi, M.; Nakamura, M.; Nishida, H.; Yap, C.C.; Suzuki, M.; Kawai, J.; et al. Antisense transcription in the mammalian transcriptome. Science 2005, 309, 1564-1566.

25. Carninci, P.; Kasukawa, T.; Katayama, S.; Gough, J.; Frith, M.C.; Maeda, N.; Oyama, R.; Ravasi, T.; Lenhard, B.; Wells, C.; et al. The transcriptional landscape of the mammalian genome. Science 2005, 309, 1559-1563.

26. Galante, P.A.; Vidal, D.O.; de Souza, J.E.; Camargo, A.A.; de Souza, S.J. Sense-antisense pairs in mammals: Functional and evolutionary considerations. Genome Biol. 2007, 8, R40.

27. Yap, K.L.; Li, S.; Munoz-Cabello, A.M.; Raguz, S.; Zeng, L.; Mujtaba, S.; Gil, J.; Walsh, M.J.; Zhou, M.M. Molecular interplay of the noncoding RNA ANRIL and methylated histone H3 lysine 27 by polycomb CBX7 in transcriptional silencing of INK4a. Mol. Cell 2010, 38, 662-674.

28. Krystal, G.W.; Armstrong, B.C.; Battey, J.F. N-myc mRNA forms an RNA-RNA duplex with endogenous antisense transcripts. Mol. Cell Biol. 1990, 10, 4180-4191.

29. Hastings, M.L.; Milcarek, C.; Martincic, K.; Peterson, M.L.; Munroe, S.H. Expression of the thyroid hormone receptor gene, erbAalpha, in B lymphocytes: Alternative mRNA processing is independent of differentiation but correlates with antisense RNA levels. Nucleic Acids Res. 1997, 25, 4296-4300.

30. Yan, M.D.; Hong, C.C.; Lai, G.M.; Cheng, A.L.; Lin, Y.W.; Chuang, S.E. Identification and characterization of a novel gene Saf transcribed from the opposite strand of Fas. Hum. Mol. Genet. 2005, 14, 1465-1474.

31. Annilo, T.; Kepp, K.; Laan, M. Natural antisense transcript of natriuretic peptide precursor A (NPPA): Structural organization and modulation of NPPA expression. BMC Mol. Biol. 2009, 10, 81.

32. Allo, M.; Buggiano, V.; Fededa, J.P.; Petrillo, E.; Schor, I.; de la Mata, M.; Agirre, E.; Plass, M.; Eyras, E.; Elela, S.A.; et al. Control of alternative splicing through siRNA-mediated transcriptional gene silencing. Nat. Struct. Mol. Biol. 2009, 16, 717-724.

33. Faghihi, M.A.; Modarresi, F.; Khalil, A.M.; Wood, D.E.; Sahagan, B.G.; Morgan, T.E.; Finch, C.E.; St Laurent, G., 3rd; Kenny, P.J.; Wahlestedt, C. Expression of a noncoding RNA is elevated in Alzheimer's disease and drives rapid feed-forward regulation of beta-secretase. Nat. Med. 2008, 14, 723-730.

34. Guil, S.; Esteller, M. cis-acting noncoding RNAs: Friends and foes. Nat. Struct. Mol. Biol. 2012, 19, 1068-1075.

35. Heintzman, N.D.; Stuart, R.K.; Hon, G.; Fu, Y.; Ching, C.W.; Hawkins, R.D.; Barrera, L.O.; Van Calcar, S.; Qu, C.; Ching, K.A.; et al. Distinct and predictive chromatin signatures of transcriptional promoters and enhancers in the human genome. Nat. Genet. 2007, 39, 311-318.

36. Heintzman, N.D.; Hon, G.C.; Hawkins, R.D.; Kheradpour, P.; Stark, A.; Harp, L.F.; Ye, Z.; Lee, L.K.; Stuart, R.K.; Ching, C.W.; et al. Histone modifications at human enhancers reflect global cell-type-specific gene expression. Nature 2009, 459, 108-112.

37. Visel, A.; Blow, M.J.; Li, Z.; Zhang, T.; Akiyama, J.A.; Holt, A.; Plajzer-Frick, I.; Shoukry, M.; Wright, C.; Chen, F.; et al. ChIP-seq accurately predicts tissue-specific activity of enhancers. Nature 2009, 457, 854-858. 
38. Kim, T.K.; Hemberg, M.; Gray, J.M.; Costa, A.M.; Bear, D.M.; Wu, J.; Harmin, D.A.; Laptewicz, M.; Barbara-Haley, K.; Kuersten, S.; et al. Widespread transcription at neuronal activity-regulated enhancers. Nature 2010, 465, 182-187.

39. Wang, D.; Garcia-Bassets, I.; Benner, C.; Li, W.; Su, X.; Zhou, Y.; Qiu, J.; Liu, W.; Kaikkonen, M.U.; Ohgi, K.A.; et al. Reprogramming transcription by distinct classes of enhancers functionally defined by eRNA. Nature 2011, 474, 390-394.

40. De Santa, F.; Barozzi, I.; Mietton, F.; Ghisletti, S.; Polletti, S.; Tusi, B.K.; Muller, H.; Ragoussis, J.; Wei, C.L.; Natoli, G. A large fraction of extragenic RNA pol II transcription sites overlap enhancers. PLoS Biol. 2010, 8, e1000384.

41. Orom, U.A.; Derrien, T.; Beringer, M.; Gumireddy, K.; Gardini, A.; Bussotti, G.; Lai, F.; Zytnicki, M.; Notredame, C.; Huang, Q.; et al. Long noncoding RNAs with enhancer-like function in human cells. Cell 2010, 143, 46-58.

42. Melo, C.A.; Drost, J.; Wijchers, P.J.; van de Werken, H.; de Wit, E.; Oude Vrielink, J.A.; Elkon, R.; Melo, S.A.; Leveille, N.; Kalluri, R.; et al. eRNAs are required for p53-dependent enhancer activity and gene transcription. Mol. Cell. 2013, 49, 524-535.

43. Lai, F.; Orom, U.A.; Cesaroni, M.; Beringer, M.; Taatjes, D.J.; Blobel, G.A.; Shiekhattar, R. Activating RNAs associate with Mediator to enhance chromatin architecture and transcription. Nature 2013, 494, 497-501.

44. Bejerano, G.; Pheasant, M.; Makunin, I.; Stephen, S.; Kent, W.J.; Mattick, J.S.; Haussler, D. Ultraconserved elements in the human genome. Science 2004, 304, 1321-1325.

45. Ahituv, N.; Zhu, Y.; Visel, A.; Holt, A.; Afzal, V.; Pennacchio, L.A.; Rubin, E.M. Deletion of ultraconserved elements yields viable mice. PLoS Biol. 2007, 5, e234.

46. Calin, G.A.; Liu, C.G.; Ferracin, M.; Hyslop, T.; Spizzo, R.; Sevignani, C.; Fabbri, M.; Cimmino, A.; Lee, E.J.; Wojcik, S.E.; et al. Ultraconserved regions encoding ncRNAs are altered in human leukemias and carcinomas. Cancer Cell. 2007, 12, 215-229.

47. Lujambio, A.; Portela, A.; Liz, J.; Melo, S.A.; Rossi, S.; Spizzo, R.; Croce, C.M.; Calin, G.A.; Esteller, M. CpG island hypermethylation-associated silencing of non-coding RNAs transcribed from ultraconserved regions in human cancer. Oncogene 2010, 29, 6390-6401.

48. Hirotsune, S.; Yoshida, N.; Chen, A.; Garrett, L.; Sugiyama, F.; Takahashi, S.; Yagami, K.; Wynshaw-Boris, A.; Yoshiki, A. An expressed pseudogene regulates the messenger-RNA stability of its homologous coding gene. Nature 2003, 423, 91-96.

49. Hawkins, P.G.; Morris, K.V. Transcriptional regulation of Oct4 by a long non-coding RNA antisense to Oct4-pseudogene 5. Transcription 2010, 1, 165-175.

50. Harrison, P.M.; Zheng, D.; Zhang, Z.; Carriero, N.; Gerstein, M. Transcribed processed pseudogenes in the human genome: An intermediate form of expressed retrosequence lacking protein-coding ability. Nucleic Acids Res. 2005, 33, 2374-2383.

51. Pink, R.C.; Wicks, K.; Caley, D.P.; Punch, E.K.; Jacobs, L.; Carter, D.R. Pseudogenes: Pseudo-functional or key regulators in health and disease? RNA 2011, 17, 792-798.

52. He, L. Posttranscriptional regulation of PTEN dosage by noncoding RNAs. Sci. Signal. 2010, 3, pe39.

53. Salmena, L.; Poliseno, L.; Tay, Y.; Kats, L.; Pandolfi, P.P. A ceRNA hypothesis: The Rosetta Stone of a hidden RNA language? Cell 2011, 146, 353-358.

54. Ledford, H. Circular RNAs throw genetics for a loop. Nature 2013, 494, 415. 
55. Kosik, K.S. Molecular biology: Circles reshape the RNA world. Nature 2013, 495, 322-324.

56. Memczak, S.; Jens, M.; Elefsinioti, A.; Torti, F.; Krueger, J.; Rybak, A.; Maier, L.; Mackowiak, S.D.; Gregersen, L.H.; Munschauer, M.; et al. Circular RNAs are a large class of animal RNAs with regulatory potency. Nature 2013, 495, 333-338.

57. Hansen, T.B.; Jensen, T.I.; Clausen, B.H.; Bramsen, J.B.; Finsen, B.; Damgaard, C.K.; Kjems, J. Natural RNA circles function as efficient microRNA sponges. Nature 2013, 495, 384-388.

58. Chu, C.; Qu, K.; Zhong, F.L.; Artandi, S.E.; Chang, H.Y. Genomic maps of long noncoding RNA occupancy reveal principles of RNA-chromatin interactions. Mol. Cell 2011, 44, 667-678.

59. Gabory, A.; Jammes, H.; Dandolo, L. The H19 locus: Role of an imprinted non-coding RNA in growth and development. Bioessays 2010, 32, 473-480.

60. Mancini-Dinardo, D.; Steele, S.J.; Levorse, J.M.; Ingram, R.S.; Tilghman, S.M. Elongation of the Kcnq1ot1 transcript is required for genomic imprinting of neighboring genes. Genes Dev. 2006, 20, 1268-1282.

61. Pauler, F.M.; Koerner, M.V.; Barlow, D.P. Silencing by imprinted noncoding RNAs: Is transcription the answer? Trends Genet. 2007, 23, 284-292.

62. Engstrom, P.G.; Suzuki, H.; Ninomiya, N.; Akalin, A.; Sessa, L.; Lavorgna, G.; Brozzi, A.; Luzi, L.; Tan, S.L.; Yang, L.; et al. Complex Loci in human and mouse genomes. PLoS Genet. 2006, 2 , e47.

63. Li, Y.; Sasaki, H. Genomic imprinting in mammals: Its life cycle, molecular mechanisms and reprogramming. Cell Res. 2011, 21, 466-473.

64. Mohammad, F.; Mondal, T.; Kanduri, C. Epigenetics of imprinted long noncoding RNAs. Epigenetics 2009, 4, 277-286.

65. Nagano, T.; Mitchell, J.A.; Sanz, L.A.; Pauler, F.M.; Ferguson-Smith, A.C.; Feil, R.; Fraser, P. The Air noncoding RNA epigenetically silences transcription by targeting G9a to chromatin. Science 2008, 322, 1717-1720.

66. Khalil, A.M.; Guttman, M.; Huarte, M.; Garber, M.; Raj, A.; Rivea Morales, D.; Thomas, K.; Presser, A.; Bernstein, B.E.; van Oudenaarden, A.; et al. Many human large intergenic noncoding RNAs associate with chromatin-modifying complexes and affect gene expression. Proc. Natl. Acad. Sci. USA 2009, 106, 11667-11672.

67. Rinn, J.L.; Kertesz, M.; Wang, J.K.; Squazzo, S.L.; Xu, X.; Brugmann, S.A.; Goodnough, L.H.; Helms, J.A.; Farnham, P.J.; Segal, E.; et al. Functional demarcation of active and silent chromatin domains in human HOX loci by noncoding RNAs. Cell 2007, 129, 1311-1323.

68. Gupta, R.A.; Shah, N.; Wang, K.C.; Kim, J.; Horlings, H.M.; Wong, D.J.; Tsai, M.C.; Hung, T.; Argani, P.; Rinn, J.L.; et al. Long non-coding RNA HOTAIR reprograms chromatin state to promote cancer metastasis. Nature 2010, 464, 1071-1076.

69. Tsai, M.C.; Manor, O.; Wan, Y.; Mosammaparast, N.; Wang, J.K.; Lan, F.; Shi, Y.; Segal, E.; and Chang, H.Y. Long noncoding RNA as modular scaffold of histone modification complexes. Science 2010, 329, 689-693.

70. Schmitz, K.M.; Mayer, C.; Postepska, A.; Grummt, I. Interaction of noncoding RNA with the rDNA promoter mediates recruitment of DNMT3b and silencing of rRNA genes. Genes Dev. 2010, 24, 2264-2269. 
71. Buske, F.A.; Mattick, J.S.; Bailey, T.L. Potential in vivo roles of nucleic acid triple-helices. RNA Biol. 2011, 8, 427-439.

72. Aguilera, A.; Garcia-Muse, T. R loops: From transcription byproducts to threats to genome stability. Mol. Cell 2012, 46, 115-124.

73. Jeon, Y.; Lee, J.T. YY1 tethers Xist RNA to the inactive X nucleation center. Cell 2011, 146, 119-133.

74. Hung, T.; Chang, H.Y. Long noncoding RNA in genome regulation: Prospects and mechanisms. RNA Biol. 2010, 7, 582-585.

75. Bonasio, R.; Tu, S.; Reinberg, D. Molecular signals of epigenetic states. Science 2010, 330, 612-616.

76. Sun, Q.; Csorba, T.; Skourti-Stathaki, K.; Proudfoot, N.J.; Dean, C. R-loop stabilization represses antisense transcription at the Arabidopsis FLC locus. Science 2013, 340, 619-621.

77. Bertani, S.; Sauer, S.; Bolotin, E.; Sauer, F. The noncoding RNA Mistral activates Hoxa6 and Hoxa7 expression and stem cell differentiation by recruiting MLL1 to chromatin. Mol. Cell 2011, 43, 1040-1046.

78. Dinger, M.E.; Amaral, P.P.; Mercer, T.R.; Pang, K.C.; Bruce, S.J.; Gardiner, B.B.; Askarian-Amiri, M.E.; Ru, K.; Solda, G.; Simons, C.; et al. Long noncoding RNAs in mouse embryonic stem cell pluripotency and differentiation. Genome Res. 2008, 18, 1433-1445.

79. Pandey, R.R.; Mondal, T.; Mohammad, F.; Enroth, S.; Redrup, L.; Komorowski, J.; Nagano, T.; Mancini-Dinardo, D.; Kanduri, C. Kcnq1 ot1 antisense noncoding RNA mediates lineage-specific transcriptional silencing through chromatin-level regulation. Mol. Cell 2008, 32, 232-246.

80. Yao, H.; Brick, K.; Evrard, Y.; Xiao, T.; Camerini-Otero, R.D.; Felsenfeld, G. Mediation of CTCF transcriptional insulation by DEAD-box RNA-binding protein p68 and steroid receptor RNA activator SRA. Genes Dev. 2010, 24, 2543-2555.

81. Wang, K.C.; Yang, Y.W.; Liu, B.; Sanyal, A.; Corces-Zimmerman, R.; Chen, Y.; Lajoie, B.R.; Protacio, A.; Flynn, R.A.; Gupta, R.A.; et al. A long noncoding RNA maintains active chromatin to coordinate homeotic gene expression. Nature 2011, 472, 120-124.

82. Feng, J.; Bi, C.; Clark, B.S.; Mady, R.; Shah, P.; Kohtz, J.D. The Evf-2 noncoding RNA is transcribed from the Dlx-5/6 ultraconserved region and functions as a Dlx-2 transcriptional coactivator. Genes Dev. 2006, 20, 1470-1484.

83. Lanz, R.B.; McKenna, N.J.; Onate, S.A.; Albrecht, U.; Wong, J.; Tsai, S.Y.; Tsai, M.J.; O'Malley, B.W. A steroid receptor coactivator, SRA, functions as an RNA and is present in an SRC-1 complex. Cell 1999, 97, 17-27.

84. Caretti, G.; Schiltz, R.L.; Dilworth, F.J.; di Padova, M.; Zhao, P.; Ogryzko, V.; Fuller-Pace, F.V.; Hoffman, E.P.; Tapscott, S.J.; Sartorelli, V. The RNA helicases p68/p72 and the noncoding RNA SRA are coregulators of MyoD and skeletal muscle differentiation. Dev. Cell. 2006, 11, 547-560.

85. Watanabe, M.; Yanagisawa, J.; Kitagawa, H.; Takeyama, K.; Ogawa, S.; Arao, Y.; Suzawa, M.; Kobayashi, Y.; Yano, T.; Yoshikawa, H.; et al. A subfamily of RNA-binding DEAD-box proteins acts as an estrogen receptor alpha coactivator through the $\mathrm{N}$-terminal activation domain (AF-1) with an RNA coactivator, SRA. EMBO J. 2001, 20, 1341-1352. 
86. Lanz, R.B.; Chua, S.S.; Barron, N.; Soder, B.M.; DeMayo, F.; O’Malley, B.W. Steroid receptor RNA activator stimulates proliferation as well as apoptosis in vivo. Mol. Cell Biol. 2003, 23, 7163-7176.

87. Kino, T.; Hurt, D.E.; Ichijo, T.; Nader, N.; Chrousos, G.P. Noncoding RNA gas5 is a growth arrest- and starvation-associated repressor of the glucocorticoid receptor. Sci. Signal. 2010, 3, ra8.

88. Willingham, A.T.; Orth, A.P.; Batalov, S.; Peters, E.C.; Wen, B.G.; Aza-Blanc, P.; Hogenesch, J.B.; Schultz, P.G. A strategy for probing the function of noncoding RNAs finds a repressor of NFAT. Science 2005, 309, 1570-1573.

89. Hung, T.; Wang, Y.; Lin, M.F.; Koegel, A.K.; Kotake, Y.; Grant, G.D.; Horlings, H.M.; Shah, N.; Umbricht, C.; Wang, P.; et al. Extensive and coordinated transcription of noncoding RNAs within cell-cycle promoters. Nat. Genet. 2011, 43, 621-629.

90. Martianov, I.; Ramadass, A.; Serra Barros, A.; Chow, N.; Akoulitchev, A. Repression of the human dihydrofolate reductase gene by a non-coding interfering transcript. Nature 2007, 445, 666-670.

91. Mazo, A.; Hodgson, J.W.; Petruk, S.; Sedkov, Y.; Brock, H.W. Transcriptional interference: An unexpected layer of complexity in gene regulation. J. Cell Sci. 2007, 120, 2755-2761.

92. Tripathi, V.; Ellis, J.D.; Shen, Z.; Song, D.Y.; Pan, Q.; Watt, A.T.; Freier, S.M.; Bennett, C.F.; Sharma, A.; Bubulya, P.A.; et al. The nuclear-retained noncoding RNA MALAT1 regulates alternative splicing by modulating SR splicing factor phosphorylation. Mol. Cell 2010, 39, 925-938.

93. Mao, Y.S.; Sunwoo, H.; Zhang, B.; Spector, D.L. Direct visualization of the co-transcriptional assembly of a nuclear body by noncoding RNAs. Nat. Cell Biol. 2011, 13, 95-101.

94. Bond, C.S.; Fox, A.H. Paraspeckles: Nuclear bodies built on long noncoding RNA. J. Cell Biol. 2009, 186, 637-644.

95. Clemson, C.M.; Hutchinson, J.N.; Sara, S.A.; Ensminger, A.W.; Fox, A.H.; Chess, A.; Lawrence, J.B. An architectural role for a nuclear noncoding RNA: NEAT1 RNA is essential for the structure of paraspeckles. Mol. Cell 2009, 33, 717-726.

96. Chen, L.L.; Carmichael, G.G. Altered nuclear retention of mRNAs containing inverted repeats in human embryonic stem cells: Functional role of a nuclear noncoding RNA. Mol. Cell 2009, 35, 467-478.

97. Sunwoo, H.; Dinger, M.E.; Wilusz, J.E.; Amaral, P.P.; Mattick, J.S.; Spector, D.L. MEN epsilon/beta nuclear-retained non-coding RNAs are up-regulated upon muscle differentiation and are essential components of paraspeckles. Genome Res. 2009, 19, 347-359.

98. Eissmann, M.; Gutschner, T.; Hammerle, M.; Gunther, S.; Caudron-Herger, M.; Gross, M.; Schirmacher, P.; Rippe, K.; Braun, T.; Zornig, M.; et al. Loss of the abundant nuclear non-coding RNA MALAT1 is compatible with life and development. RNA Biol. 2012, 9, 1076-1087.

99. Ip, J.Y.; Nakagawa, S. Long non-coding RNAs in nuclear bodies. Dev Growth Differ. 2012, 54, 44-54.

100. Nakagawa, S.; Naganuma, T.; Shioi, G.; Hirose, T. Paraspeckles are subpopulation-specific nuclear bodies that are not essential in mice. J. Cell Biol. 2011, 193, 31-39. 
101. Zhang, B.; Arun, G.; Mao, Y.S.; Lazar, Z.; Hung, G.; Bhattacharjee, G.; Xiao, X.; Booth, C.J.; $\mathrm{Wu}$, J.; Zhang, C.; et al. The lncRNA Malat1 is dispensable for mouse development but its transcription plays a cis-regulatory role in the adult. Cell Rep. 2012, 2, 111-123.

102. Yin, Q.F.; Yang, L.; Zhang, Y.; Xiang, J.F.; Wu, Y.W.; Carmichael, G.G.; Chen, L.L. Long noncoding RNAs with snoRNA ends. Mol. Cell. 2012, 48, 219-230.

103. Carrieri, C.; Cimatti, L.; Biagioli, M.; Beugnet, A.; Zucchelli, S.; Fedele, S.; Pesce, E.; Ferrer, I.; Collavin, L.; Santoro, C.; et al. Long non-coding antisense RNA controls Uchll translation through an embedded SINEB2 repeat. Nature 2012, 491, 454-457.

104. Yoon, J.H.; Abdelmohsen, K.; Srikantan, S.; Yang, X.; Martindale, J.L.; De, S.; Huarte, M.; Zhan, M.; Becker, K.G.; Gorospe, M. LincRNA-p21 suppresses target mRNA translation. Mol. Cell 2012, 47, 648-655.

105. Kretz, M.; Siprashvili, Z.; Chu, C.; Webster, D.E.; Zehnder, A.; Qu, K.; Lee, C.S.; Flockhart, R.J.; Groff, A.F.; Chow, J.; et al. Control of somatic tissue differentiation by the long non-coding RNA TINCR. Nature 2013, 493, 231-235.

106. Gong, C.; Maquat, L.E. IncRNAs transactivate STAU1-mediated mRNA decay by duplexing with 3' UTRs via Alu elements. Nature 2011, 470, 284-288.

107. Cesana, M.; Cacchiarelli, D.; Legnini, I.; Santini, T.; Sthandier, O.; Chinappi, M.; Tramontano, A.; Bozzoni, I. A long noncoding RNA controls muscle differentiation by functioning as a competing endogenous RNA. Cell 2011, 147, 358-369.

108. Cai, X.; Cullen, B.R. The imprinted H19 noncoding RNA is a primary microRNA precursor. RNA 2007, 13, 313-316.

109. Wang, K.C.; Chang, H.Y. Molecular mechanisms of long noncoding RNAs. Mol. Cell 2011, 43, 904-914.

110. Spitale, R.C.; Tsai, M.C.; Chang, H.Y. RNA templating the epigenome: Long noncoding RNAs as molecular scaffolds. Epigenetics 2011, 6, 539-543.

111. Zappulla, D.C.; Cech, T.R. RNA as a flexible scaffold for proteins: Yeast telomerase and beyond. Cold Spring Harb. Symp. Quant. Biol. 2006, 71, 217-224.

112. Kertesz, M.; Wan, Y.; Mazor, E.; Rinn, J.L.; Nutter, R.C.; Chang, H.Y.; Segal, E. Genome-wide measurement of RNA secondary structure in yeast. Nature 2010, 467, 103-107.

113. Castello, A.; Fischer, B.; Eichelbaum, K.; Horos, R.; Beckmann, B.M.; Strein, C.; Davey, N.E.; Humphreys, D.T.; Preiss, T.; Steinmetz, L.M.; et al. Insights into RNA biology from an atlas of mammalian mRNA-binding proteins. Cell 2012, 149, 1393-1406.

114. Guttman, M.; Donaghey, J.; Carey, B.W.; Garber, M.; Grenier, J.K.; Munson, G.; Young, G.; Lucas, A.B.; Ach, R.; Bruhn, L.; et al. lincRNAs act in the circuitry controlling pluripotency and differentiation. Nature 2011, 477, 295-300.

115. Sheik Mohamed, J.; Gaughwin, P.M.; Lim, B.; Robson, P.; Lipovich, L. Conserved long noncoding RNAs transcriptionally regulated by Oct 4 and Nanog modulate pluripotency in mouse embryonic stem cells. RNA 2010, 16, 324-337.

116. Taft, R.J.; Pang, K.C.; Mercer, T.R.; Dinger, M.; Mattick, J.S. Non-coding RNAs: Regulators of disease. J. Pathol. 2010, 220, 126-139. 
117. Ishii, N.; Ozaki, K.; Sato, H.; Mizuno, H.; Saito, S.; Takahashi, A.; Miyamoto, Y.; Ikegawa, S.; Kamatani, N.; Hori, M.; et al. Identification of a novel non-coding RNA, MIAT, that confers risk of myocardial infarction. J. Hum. Genet. 2006, 51, 1087-1099.

118. Pasmant, E.; Laurendeau, I.; Heron, D.; Vidaud, M.; Vidaud, D.; Bieche, I. Characterization of a germ-line deletion, including the entire INK4/ARF locus, in a melanoma-neural system tumor family: Identification of ANRIL, an antisense noncoding RNA whose expression coclusters with ARF. Cancer Res. 2007, 67, 3963-3969.

119. Sonkoly, E.; Bata-Csorgo, Z.; Pivarcsi, A.; Polyanka, H.; Kenderessy-Szabo, A.; Molnar, G.; Szentpali, K.; Bari, L.; Megyeri, K.; Mandi, Y.; et al. Identification and characterization of a novel, psoriasis susceptibility-related noncoding RNA gene, PRINS. J. Biol. Chem. 2005, 280, 24159-24167.

120. Daughters, R.S.; Tuttle, D.L.; Gao, W.; Ikeda, Y.; Moseley, M.L.; Ebner, T.J.; Swanson, M.S.; Ranum, L.P. RNA gain-of-function in spinocerebellar ataxia type 8. PLoS Genet. 2009, 5, e1000600.

121. Khalil, A.M.; Faghihi, M.A.; Modarresi, F.; Brothers, S.P.; Wahlestedt, C. A novel RNA transcript with antiapoptotic function is silenced in fragile $\mathrm{X}$ syndrome. PLoS One 2008, 3, e1486.

122. Kogo, R.; Shimamura, T.; Mimori, K.; Kawahara, K.; Imoto, S.; Sudo, T.; Tanaka, F.; Shibata, K.; Suzuki, A.; Komune, S.; et al. Long noncoding RNA HOTAIR regulates polycomb-dependent chromatin modification and is associated with poor prognosis in colorectal cancers. Cancer Res. 2011, 71, 6320-6326.

123. Chung, S.; Nakagawa, H.; Uemura, M.; Piao, L.; Ashikawa, K.; Hosono, N.; Takata, R.; Akamatsu, S.; Kawaguchi, T.; Morizono, T.; et al. Association of a novel long non-coding RNA in 8q24 with prostate cancer susceptibility. Cancer Sci. 2011, 102, 245-252.

124. Yang, Z.; Zhou, L.; Wu, L.M.; Lai, M.C.; Xie, H.Y.; Zhang, F.; Zheng, S.S. Overexpression of long non-coding RNA HOTAIR predicts tumor recurrence in hepatocellular carcinoma patients following liver transplantation. Ann. Surg. Oncol. 2011, 18, 1243-1250.

125. Lai, M.C.; Yang, Z.; Zhou, L.; Zhu, Q.Q.; Xie, H.Y.; Zhang, F.; Wu, L.M.; Chen, L.M.; Zheng, S.S. Long non-coding RNA MALAT-1 overexpression predicts tumor recurrence of hepatocellular carcinoma after liver transplantation. Med. Oncol. 2012, 29, 1810-1816.

126. Calin, G.A.; Pekarsky, Y.; Croce, C.M. The role of microRNA and other non-coding RNA in the pathogenesis of chronic lymphocytic leukemia. Best. Pract. Res. Clin. Haematol. 2007, 20, $425-437$.

127. Khaitan, D.; Dinger, M.E.; Mazar, J.; Crawford, J.; Smith, M.A.; Mattick, J.S.; Perera, R.J. The melanoma-upregulated long noncoding RNA SPRY4-IT1 modulates apoptosis and invasion. Cancer Res. 2011, 71, 3852-3862.

128. Huarte, M.; Rinn, J.L. Large non-coding RNAs: Missing links in cancer? Hum. Mol. Genet. 2010, 19, R152-R161.

129. Li, L.; Feng, T.; Lian, Y.; Zhang, G.; Garen, A.; Song, X. Role of human noncoding RNAs in the control of tumorigenesis. Proc. Natl. Acad. Sci. USA 2009, 106, 12956-12961.

130. Yu, W.; Gius, D.; Onyango, P.; Muldoon-Jacobs, K.; Karp, J.; Feinberg, A.P.; Cui, H. Epigenetic silencing of tumour suppressor gene p15 by its antisense RNA. Nature 2008, 451, 202-206. 
131. Lawrie, C.H. MicroRNAs and lymphomagenesis: A functional review. Br. J. Haematol. 2013, $160,571-581$.

132. Agirre, X.; Martinez-Climent, J.A.; Odero, M.D.; Prosper, F. Epigenetic regulation of miRNA genes in acute leukemia. Leukemia 2012, 26, 395-403.

133. Elton, T.S.; Selemon, H.; Elton, S.M.; Parinandi, N.L. Regulation of the MIR155 host gene in physiological and pathological processes. Gene 2012, doi:10.1016/j.gene.2012.12.009.

134. Vargova, K.; Curik, N.; Burda, P.; Basova, P.; Kulvait, V.; Pospisil, V.; Savvulidi, F.; Kokavec, J.; Necas, E.; Berkova, A.; et al. MYB transcriptionally regulates the miR-155 host gene in chronic lymphocytic leukemia. Blood 2011, 117, 3816-3825.

135. Nielsen, C.B.; Shomron, N.; Sandberg, R.; Hornstein, E.; Kitzman, J.; Burge, C.B. Determinants of targeting by endogenous and exogenous microRNAs and siRNAs. RNA 2007, 13, 1894-1910.

136. Ji, M.; Rao, E.; Ramachandrareddy, H.; Shen, Y.; Jiang, C.; Chen, J.; Hu, Y.; Rizzino, A.; Chan, W.C.; Fu, K.; et al. The miR-17-92 microRNA cluster is regulated by multiple mechanisms in B-cell malignancies. Am. J. Pathol. 2011, 179, 1645-1656.

137. Rinaldi, A.; Poretti, G.; Kwee, I.; Zucca, E.; Catapano, C.V.; Tibiletti, M.G.; Bertoni, F. Concomitant MYC and microRNA cluster miR-17-92 (C13orf25) amplification in human mantle cell lymphoma. Leuk Lymphoma 2007, 48, 410-412.

138. Hayashita, Y.; Osada, H.; Tatematsu, Y.; Yamada, H.; Yanagisawa, K.; Tomida, S.; Yatabe, Y.; Kawahara, K.; Sekido, Y.; Takahashi, T. A polycistronic microRNA cluster, miR-17-92, is overexpressed in human lung cancers and enhances cell proliferation. Cancer Res. 2005, 65, 9628-9632.

139. Humphreys, K.J.; Cobiac, L.; Le Leu, R.K.; Van der Hoek, M.B.; Michael, M.Z. Histone deacetylase inhibition in colorectal cancer cells reveals competing roles for members of the oncogenic miR-17-92 cluster. Mol. Carcinog. 2013, 52, 459-474.

140. Kunkeaw, N.; Jeon, S.H.; Lee, K.; Johnson, B.H.; Tanasanvimon, S.; Javle, M.; Pairojkul, C.; Chamgramol, Y.; Wongfieng, W.; Gong, B.; et al. Cell death/proliferation roles for nc886, a non-coding RNA, in the protein kinase R pathway in cholangiocarcinoma. Oncogene 2012, doi:10.1038/onc.2012.382.

141. Treppendahl, M.B.; Qiu, X.; Sogaard, A.; Yang, X.; Nandrup-Bus, C.; Hother, C.; Andersen, M.K.; Kjeldsen, L.; Mollgaard, L.; Hellstrom-Lindberg, E.; et al. Allelic methylation levels of the noncoding VTRNA2-1 located on chromosome 5q31.1 predict outcome in AML. Blood 2012, 119, 206-216.

142. He, L.; Thomson, J.M.; Hemann, M.T.; Hernando-Monge, E.; Mu, D.; Goodson, S.; Powers, S.; Cordon-Cardo, C.; Lowe, S.W.; Hannon, G.J.; et al. A microRNA polycistron as a potential human oncogene. Nature 2005, 435, 828-833.

143. Nagoshi, H.; Taki, T.; Hanamura, I.; Nitta, M.; Otsuki, T.; Nishida, K.; Okuda, K.; Sakamoto, N.; Kobayashi, S.; Yamamoto-Sugitani, M.; et al. Frequent PVT1 rearrangement and novel chimeric genes PVT1-NBEA and PVT1-WWOX occur in multiple myeloma with 8q24 abnormality. Cancer Res. 2012, 72, 4954-4962.

144. Zeidler, R.; Joos, S.; Delecluse, H.J.; Klobeck, G.; Vuillaume, M.; Lenoir, G.M.; Bornkamm, G.W.; Lipp, M. Breakpoints of Burkitt's lymphoma $t(8 ; 22)$ translocations map within a distance of $300 \mathrm{~kb}$ downstream of MYC. Genes Chromosomes Cancer 1994, 9, 282-287. 
145. Enciso-Mora, V.; Broderick, P.; Ma, Y.; Jarrett, R.F.; Hjalgrim, H.; Hemminki, K.; van den Berg, A.; Olver, B.; Lloyd, A.; Dobbins, S.E.; et al. A genome-wide association study of Hodgkin's lymphoma identifies new susceptibility loci at 2p16.1 (REL), 8q24.21 and 10p14 (GATA3). Nat. Genet. 2010, 42, 1126-1130.

146. Huppi, K.; Volfovsky, N.; Runfola, T.; Jones, T.L.; Mackiewicz, M.; Martin, S.E.; Mushinski, J.F.; Stephens, R.; Caplen, N.J. The identification of microRNAs in a genomically unstable region of human chromosome 8q24. Mol. Cancer Res. 2008, 6, 212-221.

147. Beck-Engeser, G.B.; Lum, A.M.; Huppi, K.; Caplen, N.J.; Wang, B.B.; Wabl, M. Pvt1-encoded microRNAs in oncogenesis. Retrovirology 2008, 5, 4.

148. Barsotti, A.M.; Beckerman, R.; Laptenko, O.; Huppi, K.; Caplen, N.J.; Prives, C. p53-Dependent induction of PVT1 and miR-1204. J. Biol. Chem. 2011, 287, 2509-2519.

149. Zhang, X.; Gejman, R.; Mahta, A.; Zhong, Y.; Rice, K.A.; Zhou, Y.; Cheunsuchon, P.; Louis, D.N.; Klibanski, A. Maternally expressed gene 3, an imprinted noncoding RNA gene, is associated with meningioma pathogenesis and progression. Cancer Res. 2010, 70, 2350-2358.

150. Zhou, Y.; Zhang, X.; Klibanski, A. MEG3 noncoding RNA: A tumor suppressor. J. Mol. Endocrinol. 2012, 48, R45-R53.

151. Saitou, M.; Sugimoto, J.; Hatakeyama, T.; Russo, G.; Isobe, M. Identification of the TCL6 genes within the breakpoint cluster region on chromosome 14q32 in T-cell leukemia. Oncogene 2000, 19, 2796-2802.

152. Zhang, X.; Rice, K.; Wang, Y.; Chen, W.; Zhong, Y.; Nakayama, Y.; Zhou, Y.; Klibanski, A. Maternally expressed gene 3 (MEG3) noncoding ribonucleic acid: Isoform structure, expression, and functions. Endocrinology 2010, 151, 939-947.

153. Zhou, Y.; Zhong, Y.; Wang, Y.; Zhang, X.; Batista, D.L.; Gejman, R.; Ansell, P.J.; Zhao, J.; Weng, C.; Klibanski, A. Activation of p53 by MEG3 non-coding RNA. J. Biol. Chem. 2007, 282, 24731-24742.

154. Gejman, R.; Batista, D.L.; Zhong, Y.; Zhou, Y.; Zhang, X.; Swearingen, B.; Stratakis, C.A.; Hedley-Whyte, E.T.; Klibanski, A. Selective loss of MEG3 expression and intergenic differentially methylated region hypermethylation in the MEG3/DLK1 locus in human clinically nonfunctioning pituitary adenomas. J. Clin. Endocrinol. Metab. 2008, 93, 4119-4125.

155. Benetatos, L.; Vartholomatos, G.; Hatzimichael, E. MEG3 imprinted gene contribution in tumorigenesis. Int. J. Cancer. 2011, 129, 773-779.

156. Garding, A.; Bhattacharya, N.; Claus, R.; Ruppel, M.; Tschuch, C.; Filarsky, K.; Idler, I.; Zucknick, M.; Caudron-Herger, M.; Oakes, C.; et al. Epigenetic upregulation of lncRNAs at $13 q 14.3$ in leukemia is linked to the in cis downregulation of a gene cluster that targets NF-kB. PLoS Genet. 2013, 9, e1003373.

157. Takeuchi, S.; Hofmann, W.K.; Tsukasaki, K.; Takeuchi, N.; Ikezoe, T.; Matsushita, M.; Uehara, Y.; Phillip Koeffler, H. Loss of H19 imprinting in adult T-cell leukaemia/lymphoma. Br. J. Haematol. 2007, 137, 380-381.

158. Li, J.; Rhodes, J.C.; Askew, D.S. Evolutionary conservation of putative functional domains in the human homolog of the murine His-1 gene. Gene 1997, 184, 169-176. 
159. Dallosso, A.R.; Hancock, A.L.; Malik, S.; Salpekar, A.; King-Underwood, L.; Pritchard-Jones, K.; Peters, J.; Moorwood, K.; Ward, A.; Malik, K.T.; et al. Alternately spliced WT1 antisense transcripts interact with WT1 sense RNA and show epigenetic and splicing defects in cancer. RNA 2007, 13, 2287-2299.

160. Ellis, B.C.; Molloy, P.L.; Graham, L.D. CRNDE: A long non-coding RNA involved in CanceR, neurobiology, and development. Front. Genet. 2012, 3, 270.

161. Taskinen, M.; Ranki, A.; Pukkala, E.; Jeskanen, L.; Kaitila, I.; Makitie, O. Extended follow-up of the Finnish cartilage-hair hypoplasia cohort confirms high incidence of non-Hodgkin lymphoma and basal cell carcinoma. Am. J. Med. Genet A. 2008, 146A, 2370-2375.

162. Braconi, C.; Valeri, N.; Kogure, T.; Gasparini, P.; Huang, N.; Nuovo, G.J.; Terracciano, L.; Croce, C.M.; Patel, T. Expression and functional role of a transcribed noncoding RNA with an ultraconserved element in hepatocellular carcinoma. Proc. Natl. Acad. Sci. USA 2011, 108, 786-791.

163. Yang, R.; Frank, B.; Hemminki, K.; Bartram, C.R.; Wappenschmidt, B.; Sutter, C.; Kiechle, M.; Bugert, P.; Schmutzler, R.K.; Arnold, N.; et al. SNPs in ultraconserved elements and familial breast cancer risk. Carcinogenesis 2008, 29, 351-355.

164. Zhang, X.; Lian, Z.; Padden, C.; Gerstein, M.B.; Rozowsky, J.; Snyder, M.; Gingeras, T.R.; Kapranov, P.; Weissman, S.M.; Newburger, P.E. A myelopoiesis-associated regulatory intergenic noncoding RNA transcript within the human HOXA cluster. Blood 2009, 113, 2526-2534.

165. Wagner, L.A.; Christensen, C.J.; Dunn, D.M.; Spangrude, G.J.; Georgelas, A.; Kelley, L.; Esplin, M.S.; Weiss, R.B.; Gleich, G.J. EGO, a novel, noncoding RNA gene, regulates eosinophil granule protein transcript expression. Blood 2007, 109, 5191-5198.

166. Ebralidze, A.K.; Guibal, F.C.; Steidl, U.; Zhang, P.; Lee, S.; Bartholdy, B.; Jorda, M.A.; Petkova, V.; Rosenbauer, F.; Huang, G.; et al. PU.1 expression is modulated by the balance of functional sense and antisense RNAs regulated by a shared cis-regulatory element. Genes Dev. 2008, 22, 2085-2092.

167. Hu, W.; Yuan, B.; Flygare, J.; Lodish, H.F. Long noncoding RNA-mediated anti-apoptotic activity in murine erythroid terminal differentiation. Genes Dev. 2011, 25, 2573-2578.

168. Aoki, K.; Harashima, A.; Sano, M.; Yokoi, T.; Nakamura, S.; Kibata, M.; Hirose, T. A thymus-specific noncoding RNA, Thy-ncR1, is a cytoplasmic riboregulator of MFAP4 mRNA in immature T-cell lines. BMC Mol. Biol. 2010, 11, 99.

169. Marasa, B.S.; Srikantan, S.; Martindale, J.L.; Kim, M.M.; Lee, E.K.; Gorospe, M.; Abdelmohsen, K. MicroRNA profiling in human diploid fibroblasts uncovers miR-519 role in replicative senescence. Aging (Albany NY) 2010, 2, 333-343.

170. Meyer, K.B.; Maia, A.T.; O’Reilly, M.; Ghoussaini, M.; Prathalingam, R.; Porter-Gill, P.; Ambs, S.; Prokunina-Olsson, L.; Carroll, J.; Ponder, B.A. A functional variant at a prostate cancer predisposition locus at 8q24 is associated with PVT1 expression. PLoS Genet. 2011, 7, e1002165.

171. Guan, Y.; Kuo, W.L.; Stilwell, J.L.; Takano, H.; Lapuk, A.V.; Fridlyand, J.; Mao, J.H.; Yu, M.; Miller, M.A.; Santos, J.L.; et al. Amplification of PVT1 contributes to the pathophysiology of ovarian and breast cancer. Clin. Cancer Res. 2007, 13, 5745-5755. 
172. Palumbo, A.P.; Boccadoro, M.; Battaglio, S.; Corradini, P.; Tsichlis, P.N.; Huebner, K.; Pileri, A.; Croce, C.M. Human homologue of Moloney leukemia virus integration-4 locus (MLVI-4), located 20 kilobases $3^{\prime}$ of the myc gene, is rearranged in multiple myelomas. Cancer Res. 1990, 50, 6478-6482.

173. Borg, A.; Baldetorp, B.; Ferno, M.; Olsson, H.; Sigurdsson, H. c-myc amplification is an independent prognostic factor in postmenopausal breast cancer. Int. J. Cancer. 1992, 51, 687-691.

174. You, L.; Chang, D.; Du, H.Z.; Zhao, Y.P. Genome-wide screen identifies PVT1 as a regulator of Gemcitabine sensitivity in human pancreatic cancer cells. Biochem. Biophys. Res. Commun. 2011, 407, 1-6.

175. Carramusa, L.; Contino, F.; Ferro, A.; Minafra, L.; Perconti, G.; Giallongo, A.; Feo, S. The PVT-1 oncogene is a Myc protein target that is overexpressed in transformed cells. J. Cell. Physiol. 2007, 213, 511-518.

176. Gil, J.; Peters, G. Regulation of the INK4b-ARF-INK4a tumour suppressor locus: All for one or one for all. Nat. Rev. Mol. Cell Biol. 2006, 7, 667-677.

177. Popov, N.; Gil, J. Epigenetic regulation of the INK4b-ARF-INK4a locus: In sickness and in health. Epigenetics 2010, 5, 685-690.

178. Kotake, Y.; Nakagawa, T.; Kitagawa, K.; Suzuki, S.; Liu, N.; Kitagawa, M.; Xiong, Y. Long non-coding RNA ANRIL is required for the PRC2 recruitment to and silencing of p15(INK4B) tumor suppressor gene. Oncogene 2011, 30, 1956-1962.

179. Pasmant, E.; Sabbagh, A.; Vidaud, M.; Bieche, I. ANRIL, a long, noncoding RNA, is an unexpected major hotspot in GWAS. FASEB J. 2011, 25, 444-448.

180. Burd, C.E.; Jeck, W.R.; Liu, Y.; Sanoff, H.K.; Wang, Z.; Sharpless, N.E. Expression of linear and novel circular forms of an INK4/ARF-associated non-coding RNA correlates with atherosclerosis risk. PLoS Genet. 2010, 6, e1001233.

181. Liu, Y.; Sanoff, H.K.; Cho, H.; Burd, C.E.; Torrice, C.; Mohlke, K.L.; Ibrahim, J.G.; Thomas, N.E.; Sharpless, N.E. INK4/ARF transcript expression is associated with chromosome 9p21 variants linked to atherosclerosis. PLoS One 2009, 4, e5027.

182. Cunnington, M.S.; Santibanez Koref, M.; Mayosi, B.M.; Burn, J.; Keavney, B. Chromosome 9p21 SNPs associated with multiple disease phenotypes correlate with anril expression. PLoS Genet. 2010, 6, e1000899.

183. Iacobucci, I.; Sazzini, M.; Garagnani, P.; Ferrari, A.; Boattini, A.; Lonetti, A.; Papayannidis, C.; Mantovani, V.; Marasco, E.; Ottaviani, E.; et al. A polymorphism in the chromosome 9p21 ANRIL locus is associated to Philadelphia positive acute lymphoblastic leukemia. Leuk Res. 2011, 35, 1052-1059.

184. Miyoshi, N.; Wagatsuma, H.; Wakana, S.; Shiroishi, T.; Nomura, M.; Aisaka, K.; Kohda, T.; Surani, M.A.; Kaneko-Ishino, T.; Ishino, F. Identification of an imprinted gene, Meg3/Gt12 and its human homologue MEG3, first mapped on mouse distal chromosome 12 and human chromosome 14q. Genes Cells 2000, 5, 211-220.

185. Zhang, X.; Zhou, Y.; Mehta, K.R.; Danila, D.C.; Scolavino, S.; Johnson, S.R.; Klibanski, A. A pituitary-derived MEG3 isoform functions as a growth suppressor in tumor cells. J. Clin. Endocrinol. Metab. 2003, 88, 5119-5126. 
186. Braconi, C.; Kogure, T.; Valeri, N.; Huang, N.; Nuovo, G.; Costinean, S.; Negrini, M.; Miotto, E.; Croce, C.M.; Patel, T. microRNA-29 can regulate expression of the long non-coding RNA gene MEG3 in hepatocellular cancer. Oncogene 2011, 30, 4750-4756.

187. Hagan, J.P.; O’Neill, B.L.; Stewart, C.L.; Kozlov, S.V.; Croce, C.M. At least ten genes define the imprinted Dlk1-Dio3 cluster on mouse chromosome 12qF1. PLoS One 2009, 4, e4352.

188. Schuster-Gossler, K.; Bilinski, P.; Sado, T.; Ferguson-Smith, A.; Gossler, A. The mouse Gt12 gene is differentially expressed during embryonic development, encodes multiple alternatively spliced transcripts, and may act as an RNA. Dev. Dyn. 1998, 212, 214-228.

189. Mondal, T.; Rasmussen, M.; Pandey, G.K.; Isaksson, A.; Kanduri, C. Characterization of the RNA content of chromatin. Genome Res. 2010, 20, 899-907.

190. Gordon, F.E.; Nutt, C.L.; Cheunsuchon, P.; Nakayama, Y.; Provencher, K.A.; Rice, K.A.; Zhou, Y.; Zhang, X.; Klibanski, A. Increased expression of angiogenic genes in the brains of mouse meg3-null embryos. Endocrinology 2010, 151, 2443-2452.

191. Ying, L.; Huang, Y.; Chen, H.; Wang, Y., Xia, L.; Chen, Y.; Liu, Y.; Qiu, F. Downregulated MEG3 activates autophagy and increases cell proliferation in bladder cancer. Mol. Biosyst. 2013, 9, 407-411.

192. Dal Bo, M.; Rossi, F.M.; Rossi, D.; Deambrogi, C.; Bertoni, F.; Del Giudice, I.; Palumbo, G.; Nanni, M.; Rinaldi, A.; Kwee, I.; et al. 13q14 deletion size and number of deleted cells both influence prognosis in chronic lymphocytic leukemia. Genes Chromosomes Cancer 2011, 50, 633-643.

193. Cimmino, A.; Calin, G.A.; Fabbri, M.; Iorio, M.V.; Ferracin, M.; Shimizu, M.; Wojcik, S.E.; Aqeilan, R.I.; Zupo, S.; Dono, M.; et al. miR-15 and miR-16 induce apoptosis by targeting BCL2. Proc. Natl. Acad. Sci. USA 2005, 102, 13944-13949.

194. Klein, U.; Lia, M.; Crespo, M.; Siegel, R.; Shen, Q.; Mo, T.; Ambesi-Impiombato, A.; Califano, A.; Migliazza, A.; Bhagat, G.; et al. The DLEU2/miR-15a/16-1 cluster controls B cell proliferation and its deletion leads to chronic lymphocytic leukemia. Cancer Cell 2010, 17, 28-40.

195. Lerner, M.; Harada, M.; Loven, J.; Castro, J.; Davis, Z.; Oscier, D.; Henriksson, M.; Sangfelt, O.; Grander, D.; Corcoran, M.M. DLEU2, frequently deleted in malignancy, functions as a critical host gene of the cell cycle inhibitory microRNAs miR-15a and miR-16-1. Exp. Cell Res. 2009, 315, 2941-2952.

196. Coccia, E.M.; Cicala, C.; Charlesworth, A.; Ciccarelli, C.; Rossi, G.B.; Philipson, L.; Sorrentino, V. Regulation and expression of a growth arrest-specific gene (gas5) during growth, differentiation, and development. Mol. Cell Biol. 1992, 12, 3514-3521.

197. Mourtada-Maarabouni, M.; Pickard, M.R.; Hedge, V.L.; Farzaneh, F.; Williams, G.T. GAS5, a non-protein-coding RNA, controls apoptosis and is downregulated in breast cancer. Oncogene 2009, 28, 195-208.

198. Williams, G.T.; Mourtada-Maarabouni, M.; Farzaneh, F. A critical role for non-coding RNA GAS5 in growth arrest and rapamycin inhibition in human T-lymphocytes. Biochem. Soc. Trans. 2011, 39, 482-486.

199. Mourtada-Maarabouni, M.; Hasan, A.M.; Farzaneh, F.; Williams, G.T. Inhibition of human T-cell proliferation by mammalian target of rapamycin (mTOR) antagonists requires noncoding RNA growth-arrest-specific transcript 5 (GAS5). Mol. Pharmacol. 2010, 78, 19-28. 
200. Barsyte-Lovejoy, D.; Lau, S.K.; Boutros, P.C.; Khosravi, F.; Jurisica, I.; Andrulis, I.L.; Tsao, M.S.; Penn, L.Z. The c-Myc oncogene directly induces the H19 noncoding RNA by allele-specific binding to potentiate tumorigenesis. Cancer Res. 2006, 66, 5330-5337.

201. Hibi, K.; Nakamura, H.; Hirai, A.; Fujikake, Y.; Kasai, Y.; Akiyama, S.; Ito, K.; Takagi, H. Loss of H19 imprinting in esophageal cancer. Cancer Res. 1996, 56, 480-482.

202. Fellig, Y.; Ariel, I.; Ohana, P.; Schachter, P.; Sinelnikov, I.; Birman, T.; Ayesh, S.; Schneider, T.; de Groot, N.; Czerniak, A.; et al. H19 expression in hepatic metastases from a range of human carcinomas. J. Clin. Pathol. 2005, 58, 1064-1068.

203. Matouk, I.J.; DeGroot, N.; Mezan, S.; Ayesh, S.; Abu-lail, R.; Hochberg, A.; Galun, E. The H19 non-coding RNA is essential for human tumor growth. PLoS One 2007, 2, e845.

204. Berteaux, N.; Lottin, S.; Monte, D.; Pinte, S.; Quatannens, B.; Coll, J.; Hondermarck, H.; Curgy, J.J.; Dugimont, T.; Adriaenssens, E. H19 mRNA-like noncoding RNA promotes breast cancer cell proliferation through positive control by E2F1. J. Biol. Chem. 2005, 280, 29625-29636.

205. Nunez, C.; Bashein, A.M.; Brunet, C.L.; Hoyland, J.A.; Freemont, A.J.; Buckle, A.M.; Murphy, C.; Cross, M.A.; Lucas, G.; Bostock, V.J.; et al. Expression of the imprinted tumour-suppressor gene H19 is tightly regulated during normal haematopoiesis and is reduced in haematopoietic precursors of patients with the myeloproliferative disease polycythaemia vera. J. Pathol. 2000, 190, 61-68.

206. Bock, O.; Schlue, J.; Kreipe, H. Reduced expression of H19 in bone marrow cells from chronic myeloproliferative disorders. Leukemia 2003, 17, 815-816.

207. Tessema, M.; Langer, F.; Bock, O.; Seltsam, A.; Metzig, K.; Hasemeier, B.; Kreipe, H.; Lehmann, U. Down-regulation of the IGF-2/H19 locus during normal and malignant hematopoiesis is independent of the imprinting pattern. Int. J. Oncol. 2005, 26, 499-507.

208. Dugimont, T.; Montpellier, C.; Adriaenssens, E.; Lottin, S.; Dumont, L.; Iotsova, V.; Lagrou, C.; Stehelin, D.; Coll, J.; Curgy, J.J. The H19 TATA-less promoter is efficiently repressed by wild-type tumor suppressor gene product p53. Oncogene 1998, 16, 2395-2401.

209. Farnebo, M.; Bykov, V.J.; Wiman, K.G. The p53 tumor suppressor: A master regulator of diverse cellular processes and therapeutic target in cancer. Biochem. Biophys. Res. Commun. 2010, 396, 85-89.

210. Tsang, W.P.; Ng, E.K.; Ng, S.S.; Jin, H.; Yu, J.; Sung, J.J.; Kwok, T.T. Oncofetal H19-derived miR-675 regulates tumor suppressor RB in human colorectal cancer. Carcinogenesis 2010, 31, $350-358$.

211. Yoshimizu, T.; Miroglio, A.; Ripoche, M.A.; Gabory, A.; Vernucci, M.; Riccio, A.; Colnot, S.; Godard, C.; Terris, B.; Jammes, H.; et al. The H19 locus acts in vivo as a tumor suppressor. Proc. Natl. Acad. Sci. USA 2008, 105, 12417-12422.

212. Leighton, P.A.; Saam, J.R.; Ingram, R.S.; Stewart, C.L.; Tilghman, S.M. An enhancer deletion affects both H19 and Igf2 expression. Genes Dev. 1995, 9, 2079-2089.

213. Scaruffi, P.; Stigliani, S.; Moretti, S.; Coco, S.; De Vecchi, C.; Valdora, F.; Garaventa, A.; Bonassi, S.; Tonini, G.P. Transcribed-Ultra Conserved Region expression is associated with outcome in high-risk neuroblastoma. BMC Cancer 2009, 9, 441.

214. Mestdagh, P.; Fredlund, E.; Pattyn, F.; Rihani, A.; Van Maerken, T.; Vermeulen, J.; Kumps, C.; Menten, B.; de Preter, K.; Schramm, A.; et al. An integrative genomics screen uncovers ncRNA T-UCR functions in neuroblastoma tumours. Oncogene 2010, 29, 3583-3592. 
215. Sana, J.; Hankeova, S.; Svoboda, M.; Kiss, I.; Vyzula, R.; Slaby, O. Expression levels of transcribed ultraconserved regions uc. 73 and uc.388 are altered in colorectal cancer. Oncology 2012, 82, 114-118.

216. Rossi, S.; Sevignani, C.; Nnadi, S.C.; Siracusa, L.D.; Calin, G.A. Cancer-associated genomic regions (CAGRs) and noncoding RNAs: Bioinformatics and therapeutic implications. Mamm. Genome. 2008, 19, 526-540.

217. Ng, D.; Toure, O.; Wei, M.H.; Arthur, D.C.; Abbasi, F.; Fontaine, L.; Marti, G.E.; Fraumeni, J.F., Jr.; Goldin, L.R.; Caporaso, N.; et al. Identification of a novel chromosome region, 13q21.33-q22.2, for susceptibility genes in familial chronic lymphocytic leukemia. Blood 2007, 109, 916-925.

218. Calin, G.A.; Ferracin, M.; Cimmino, A.; Di Leva, G.; Shimizu, M.; Wojcik, S.E.; Iorio, M.V.; Visone, R.; Sever, N.I.; Fabbri, M.; et al. A MicroRNA signature associated with prognosis and progression in chronic lymphocytic leukemia. N. Engl. J. Med. 2005, 353, 1793-1801.

219. Notari, M.; Neviani, P.; Santhanam, R.; Blaser, B.W.; Chang, J.S.; Galietta, A.; Willis, A.E.; Roy, D.C.; Caligiuri, M.A.; Marcucci, G.; et al. A MAPK/HNRPK pathway controls BCR/ABL oncogenic potential by regulating MYC mRNA translation. Blood 2006, 107, 2507-2516.

220. Du, Q.; Wang, L.; Zhu, H.; Zhang, S.; Xu, L.; Zheng, W.; Liu, X. The role of heterogeneous nuclear ribonucleoprotein $\mathrm{K}$ in the progression of chronic myeloid leukemia. Med. Oncol. 2010, 27, 673-679.

221. Tsujimoto, Y.; Gorham, J.; Cossman, J.; Jaffe, E.; Croce, C.M. The t(14;18) chromosome translocations involved in B-cell neoplasms result from mistakes in VDJ joining. Science 1985, 229, 1390-1393.

222. Ridanpaa, M.; van Eenennaam, H.; Pelin, K.; Chadwick, R.; Johnson, C.; Yuan, B.; vanVenrooij, W.; Pruijn, G.; Salmela, R.; Rockas, S.; et al. Mutations in the RNA component of RNase MRP cause a pleiotropic human disease, cartilage-hair hypoplasia. Cell 2001, 104, 195-203.

223. Tanaka, R.; Satoh, H.; Moriyama, M.; Satoh, K.; Morishita, Y.; Yoshida, S.; Watanabe, T.; Nakamura, Y.; Mori, S. Intronic U50 small-nucleolar-RNA (snoRNA) host gene of no protein-coding potential is mapped at the chromosome breakpoint $t(3 ; 6)(\mathrm{q} 27 ; \mathrm{q} 15)$ of human B-cell lymphoma. Genes Cells 2000, 5, 277-287.

224. Zhao, H.; Zhang, X.; Frazao, J.B.; Condino-Neto, A.; Newburger, P.E. HOX antisense lincRNA HOXA-AS2 is an apoptosis repressor in all trans retinoic acid treated NB4 promyelocytic leukemia cells. J. Cell Biochem. 2013, doi:10.1002/jcb.24586.

225. Paralkar, V.R.; Weiss, M.J. A new 'Linc' between noncoding RNAs and blood development. Genes Dev. 2011, 25, 2555-2558.

226. Halvorsen, M.; Martin, J.S.; Broadaway, S.; Laederach, A. Disease-associated mutations that alter the RNA structural ensemble. PLoS Genet. 2010, 6, e1001074.

227. Wojcik, S.E.; Rossi, S.; Shimizu, M.; Nicoloso, M.S.; Cimmino, A.; Alder, H.; Herlea, V.; Rassenti, L.Z.; Rai, K.R.; Kipps, T.J.; et al. Non-codingRNA sequence variations in human chronic lymphocytic leukemia and colorectal cancer. Carcinogenesis 2010, 31, 208-215.

228. Scott, L.J.; Mohlke, K.L.; Bonnycastle, L.L.; Willer, C.J.; Li, Y.; Duren, W.L.; Erdos, M.R.; Stringham, H.M.; Chines, P.S.; Jackson, A.U.; et al. A genome-wide association study of type 2 diabetes in Finns detects multiple susceptibility variants. Science 2007, 316, 1341-1345. 
229. Broadbent, H.M.; Peden, J.F.; Lorkowski, S.; Goel, A.; Ongen, H.; Green, F.; Clarke, R.; Collins, R.; Franzosi, M.G.; Tognoni, G.; et al. Susceptibility to coronary artery disease and diabetes is encoded by distinct, tightly linked SNPs in the ANRIL locus on chromosome 9p. Hum. Mol. Genet. 2008, 17, 806-814.

230. Morrison, L.E.; Jewell, S.S.; Usha, L.; Blondin, B.A.; Rao, R.D.; Tabesh, B.; Kemper, M.; Batus, M.; Coon, J.S. Effects of ERBB2 amplicon size and genomic alterations of chromosomes 1, 3, and 10 on patient response to trastuzumab in metastatic breast cancer. Genes Chromosomes Cancer 2007, 46, 397-405.

231. Nupponen, N.N.; Carpten, J.D. Prostate cancer susceptibility genes: Many studies, many results, no answers. Cancer Metastasis Rev. 2001, 20, 155-164.

232. Smedley, D.; Sidhar, S.; Birdsall, S.; Bennett, D.; Herlyn, M.; Cooper, C.; Shipley, J. Characterization of chromosome 1 abnormalities in malignant melanomas. Genes Chromosomes Cancer 2000, 28, 121-125.

233. Kagami, M.; O'Sullivan, M.J.; Green, A.J.; Watabe, Y.; Arisaka, O.; Masawa, N.; Matsuoka, K.; Fukami, M.; Matsubara, K.; Kato, F.; et al. The IG-DMR and the MEG3-DMR at human chromosome 14q32.2: Hierarchical interaction and distinct functional properties as imprinting control centers. PLoS Genet. 2010, 6, e1000992.

234. Astuti, D.; Latif, F.; Wagner, K.; Gentle, D.; Cooper, W.N.; Catchpoole, D.; Grundy, R.; Ferguson-Smith, A.C.; Maher, E.R. Epigenetic alteration at the DLK1-GTL2 imprinted domain in human neoplasia: Analysis of neuroblastoma, phaeochromocytoma and Wilms' tumour. Br. J. Cancer. 2005, 92, 1574-1580.

235. Benetatos, L.; Hatzimichael, E.; Dasoula, A.; Dranitsaris, G.; Tsiara, S.; Syrrou, M.; Georgiou, I.; Bourantas, K.L. CpG methylation analysis of the MEG3 and SNRPN imprinted genes in acute myeloid leukemia and myelodysplastic syndromes. Leuk Res. 2010, 34, 148-153.

236. Khoury, H.; Suarez-Saiz, F.; Wu, S.; Minden, M.D. An upstream insulator regulates DLK1 imprinting in AML. Blood 2010, 115, 2260-2263.

237. Rojas, J.J.; Guedan, S.; Searle, P.F.; Martinez-Quintanilla, J.; Gil-Hoyos, R.; Alcayaga-Miranda, F.; Cascallo, M.; Alemany, R. Minimal RB-responsive E1A promoter modification to attain potency, selectivity, and transgene-arming capacity in oncolytic adenoviruses. Mol. Ther. 2010, 18, 1960-1971.

238. Castello, A.; Horos, R.; Strein, C.; Fischer, B.; Eichelbaum, K.; Steinmetz, L.M.; Krijgsveld, J.; Hentze, M.W. System-wide identification of RNA-binding proteins by interactome capture. Nat. Protoc. 2013, 8, 491-500.

239. Fan, M.; Li, X.; Jiang, W.; Huang, Y.; Li, J.; Wang, Z. A long non-coding RNA, PTCSC3, as a tumor suppressor and a target of miRNAs in thyroid cancer cells. Exp. Ther. Med. 2013, 5, $1143-1146$.

240. Chung, C.C.; Chanock, S.J. Current status of genome-wide association studies in cancer. Hum. Genet. 2011, 130, 59-78.

241. Giacomini, K.M.; Brett, C.M.; Altman, R.B.; Benowitz, N.L.; Dolan, M.E.; Flockhart, D.A.; Johnson, J.A.; Hayes, D.F.; Klein, T.; Krauss, R.M.; et al. The pharmacogenetics research network: From SNP discovery to clinical drug response. Clin. Pharmacol. Ther. 2007, 81, 328-345.

242. Mattick, J.S. The genetic signatures of noncoding RNAs. PLoS Genet. 2009, 5, e1000459. 
243. Prensner, J.R.; Iyer, M.K.; Balbin, O.A.; Dhanasekaran, S.M.; Cao, Q.; Brenner, J.C.; Laxman, B.; Asangani, I.A.; Grasso, C.S.; Kominsky, H.D.; et al. Transcriptome sequencing across a prostate cancer cohort identifies PCAT-1, an unannotated lincRNA implicated in disease progression. Nat. Biotechnol. 2011, 29, 742-749.

244. Matouk, I.J.; Abbasi, I.; Hochberg, A.; Galun, E.; Dweik, H.; Akkawi, M. Highly upregulated in liver cancer noncoding RNA is overexpressed in hepatic colorectal metastasis. Eur. J. Gastroenterol. Hepatol. 2009, 21, 688-692.

245. Panzitt, K.; Tschernatsch, M.M.; Guelly, C.; Moustafa, T.; Stradner, M.; Strohmaier, H.M.; Buck, C.R.; Denk, H.; Schroeder, R.; Trauner, M.; et al. Characterization of HULC, a novel gene with striking up-regulation in hepatocellular carcinoma, as noncoding RNA. Gastroenterology 2007, 132, 330-342.

246. De Kok, J.B.; Verhaegh, G.W.; Roelofs, R.W.; Hessels, D.; Kiemeney, L.A.; Aalders, T.W.; Swinkels, D.W.; Schalken, J.A. DD3(PCA3), a very sensitive and specific marker to detect prostate tumors. Cancer Res. 2002, 62, 2695-2698.

247. Ifere, G.O.;Ananaba, G.A. Prostate cancer gene expression marker 1 (PCGEM1): A patented prostate- specific non-coding gene and regulator of prostate cancer progression. Recent Pat. DNA Gene Seq. 2009, 3, 151-163.

248. Lee, G.L.; Dobi, A.; Srivastava, S. Prostate cancer: Diagnostic performance of the PCA3 urine test. Nat. Rev. Urol. 2011, 8, 123-124.

249. Tomlins, S.A.; Aubin, S.M.; Siddiqui, J.; Lonigro, R.J.; Sefton-Miller, L.; Miick, S.; Williamsen, S.; Hodge, P.; Meinke, J.; Blase, A.; et al. Urine TMPRSS2:ERG fusion transcript stratifies prostate cancer risk in men with elevated serum PSA. Sci. Transl. Med. 2011, 3, 94ra72.

250. Durand, X.; Moutereau, S.; Xylinas, E.; de la Taille, A. Progensa PCA3 test for prostate cancer. Expert Rev. Mol. Diagn. 2011, 11, 137-144.

251. Niinuma, T.; Suzuki, H.; Nojima, M.; Nosho, K.; Yamamoto, H.; Takamaru, H.; Yamamoto, E.; Maruyama, R.; Nobuoka, T.; Miyazaki, Y.; et al. Upregulation of miR-196a and HOTAIR drive malignant character in gastrointestinal stromal tumors. Cancer Res. 2012, 72, 1126-1136.

252. Geng, Y.J.; Xie, S.L.; Li, Q.; Ma, J.; Wang, G.Y. Large intervening non-coding RNA HOTAIR is associated with hepatocellular carcinoma progression. J. Int. Med. Res. 2011, 39, 2119-2128.

253. Ji, P.; Diederichs, S.; Wang, W.; Boing, S.; Metzger, R.; Schneider, P.M.; Tidow, N.; Brandt, B.; Buerger, H.; Bulk, E.; et al. MALAT-1, a novel noncoding RNA, and thymosin beta4 predict metastasis and survival in early-stage non-small cell lung cancer. Oncogene 2003, 22, 8031-8041.

254. Huang, K.C.; Rao, P.H.; Lau, C.C.; Heard, E.; Ng, S.K.; Brown, C.; Mok, S.C.; Berkowitz, R.S.; $\mathrm{Ng}$, S.W. Relationship of XIST expression and responses of ovarian cancer to chemotherapy. Mol. Cancer Ther. 2002, 1, 769-776.

255. Tsai, M.C.; Spitale, R.C.; Chang, H.Y. Long intergenic noncoding RNAs: New links in cancer progression. Cancer Res. 2011, 71, 3-7.

(C) 2013 by the authors; licensee MDPI, Basel, Switzerland. This article is an open access article distributed under the terms and conditions of the Creative Commons Attribution license (http://creativecommons.org/licenses/by/3.0/). 